\title{
Impairment of the GßY-SNAP25 brake on exocytosis enhances insulin action, protects against diet-induced obesity, and promotes adipocyte browning
}

Ryan P. Ceddia ${ }^{1, *}$, Zack Zurawski ${ }^{2,3, *}$, Analisa Thompson Gray², Feyisayo Adegboye ${ }^{2}$, Fubiao Shi ${ }^{1}$, Dianxin Liu ${ }^{1}$, Owen P. McGuinness ${ }^{4}$, Sheila Collins ${ }^{1,4}$, Heidi E. Hamm²

${ }^{1}$ Department of Medicine, Division of Cardiovascular Medicine, Vanderbilt University Medical Center, Nashville, TN 37232, USA

2Department of Pharmacology, Vanderbilt University, Nashville, TN 37232, USA

${ }^{3}$ Department of Anatomy and Cell Biology, University of Illinois at Chicago, Chicago, IL 60612, USA.

${ }^{4}$ Department of Molecular Physiology and Biophysics, Vanderbilt University, Nashville, TN 37232, USA

*These authors contributed equally to this work.

Corresponding author and person to whom reprints should be addressed:

Heidi Hamm, Ph.D.

Vanderbilt University

442 Robinson Research Building

Nashville, TN 37212

Tel: 615-343-9536

Email: heidi.hamm@vanderbilt.edu 
The GßY complex inhibits vesicle exocytosis by two mechanisms: inhibiting calcium entry by binding to voltage gated calcium channels, and binding to SNAP25 in the SNAP Receptor (SNARE) complex. To de-convolute the role of each of these mechanisms in vivo, we have made a mouse with the second mechanism disabled. The SNAP25 33 mutation renders the SNARE complex deficient in binding to G $\beta y$ and was used to investigate the importance of the GßY-SNAP25 interaction in glucose stimulated insulin secretion (GSIS) and global metabolic homeostasis. GSIS and $\alpha_{2 A}$ adrenergic receptor-mediated inhibition of GSIS were not altered in SNAP $25^{\Delta 3 / \Delta 3}$ mice. Nevertheless, SNAP25 $5^{\Delta 3 / \Delta 3}$ mice exhibited a marked improvement in insulin sensitivity and were resistant to weight gain when challenged with a high fat diet (HFD). Reduced food consumption in the early stages of HFD feeding were partly responsible for the inability of SNAP $25^{\Delta 3 / \Delta 3}$ mice to gain weight on HFD. Additionally, improved insulin-mediated glucose uptake into white adipose tissue and increased 'browning' were observed in SNAP $25^{\Delta 3 / \Delta 3}$ mice, which is consistent with an impaired ability to retain energy stores. These phenotypic changes in SNAP25 $5^{\Delta 3 / \Delta 3}$ mice are all metabolically protective, indicating that pharmacological targeting of the $\mathrm{G} \beta \gamma^{-}$ SNAP25 interaction may have a metabolic benefit. 


\section{Introduction:}

G-protein coupled receptors (GPCRs) are canonically known to mediate downstream signaling events through the activation of heterotrimeric G-proteins. While the classical Ga-mediated signaling events are well known, and many represent important pharmacological targets (1), signaling via the Gßy-subunits have received less attention and the therapeutic targeting of these signaling pathways has not been as widely exploited (2). One function of $\mathrm{G} \beta \mathrm{y}$ is to inhibit exocytosis by two mechanisms, modulation of calcium entry, and direct binding to the exocytotic fusion complex (3). We have shown that Gßy binding to the SNARE complex is mainly through the last three amino acids of SNAP25 (Soluble $N$-ethylmaleimide-sensitive factor Attachment Protein), in the SNAP Receptor (SNARE) complex (4). In order to specifically study the contribution of exocytosis at the exocytotic fusion step in vivo, we developed an allele of SNAP25 which lacks these last three amino acids, which we have called SNAP25 $\Delta 3$ (5). The ability of SNAP25 $\Delta 3$ to form SNARE complexes that undergo calciumsynaptotagmin mediated zipping and regulate exocytosis is identical to that of SNAP25, but its ability to interact with Gßy, and GPCR-mediated inhibitory effects on exocytosis, is ablated. The SNAP25 $25^{\Delta 3 / \Delta 3}$ mouse has demonstrated the importance of the GBY-SNARE pathway in a number of neurological processes, including stress and pain processing, as well as long-term potentiation (6) and spatial memory (5). We hypothesized that the SNAP25 $5^{\Delta 3 / \Delta 3}$ mouse may have an altered metabolic phenotype because neurological processes use SNAREdependent signals to regulate a number of metabolically important processes, such as feeding behavior, energy balance, and thermoregulation (7-12), and the secretion of important metabolic hormones, such as insulin (1315).

Metabolic diseases, such as diabetes and obesity, are estimated to have an annual global economic impact in the trillions of (US) dollars (16-20). The therapeutic value of the recently developed glutides and gliptins highlights the benefits of pharmacological agents that augment glucose stimulated insulin secretion (GSIS) (21). We hypothesized that the SNAP25 $\Delta 3$ mutation would similarly enhance GSIS because previous studies have indicated that norepinephrine inhibits insulin exocytosis via the $\alpha_{2 A}$ adrenergic receptor (AR) through $G \beta Y$ inhibition of SNARE in the pancreatic $\beta$-cell (22). While the recent advances that have led to these anti-diabetic agents, a lack of effective therapeutics for obesity persists. Obesity is co-morbid with insulin resistance and type II diabetes in addition to many other diseases such as cancer, asthma, mental disorders, nonalcoholic fatty liver disease, cardiovascular diseases, and heart failure $(23,24)$. This lack of obesity therapeutics is a serious 
deficiency in the currently available pharmacological cornucopia, as recent studies have reported that about $40 \%$ of Americans are clinically obese and the prevalence of obesity worldwide is rising (25).

We took advantage of the $\beta$ y-SNAP25 interaction and its ability to serve as a brake on secretion to determine if limiting this physiologic inhibitory pathway could affect insulin secretion and/or weight gain in response to a high fat diet. Though SNAP25 is a well-known component of the insulin exocytosis machinery (1315), we observed no alteration in GSIS from SNAP25 $23 / \Delta 3$ mice. However, adiposity and glucose homeostasis were markedly improved. These studies went on to probe the basis for this metabolic protection by examining energy intake and energy expenditure, and potential cellular targets that contribute to this protection. Though SNAP $25^{\Delta 3 / \Delta 3}$ mice did not exhibit enhanced GSIS, their resistance to diet induced obesity and improved glucose homeostasis suggest that targeting of the GßY-SNAP25 interaction may have therapeutic benefits for metabolic diseases.

\section{Results:}

In order to test our hypothesis that removal of the Gßy inhibition of SNAP25-mediated exocytosis would improve insulin secretion, we measured circulating glucose and insulin levels in SNAP25 $\Delta 3$ mice during a glucose tolerance test (GTT). In our first study, 14 week-old, chow fed male mice (weighing $29.3 \pm 0.710 \mathrm{~g}$ vs. 28.9 $\pm 0.749 \mathrm{~g}, \mathrm{SNAP}_{25^{+/+}}$vs. SNAP25 $5^{\Delta 3 / \Delta 3}$ respectively, $\left.\mathrm{P}=0.695\right)$ received an IP injection of $2 \mathrm{mg} / \mathrm{kg}$ glucose. The SNAP25 $5^{\Delta 3 / \Delta 3}$ mice had a normal glucose tolerance compared to SNAP25 $5^{+/}$mice (Fig. 1A). Plasma insulin was measured during the IP-GTT. We found that insulin levels in SNAP25 $23 / \Delta 3$ mice showed a significantly reduced insulin response at 15 and 30 minutes compared to SNAP25 $5^{+/+}$mice (Fig. 1B). In a separate cohort ofchow fed male mice $\left(28.2 \pm 0.753 \mathrm{~g}\right.$ vs. $27.3 \pm 0.596 \mathrm{~g}$, SNAP2 $5^{+/+}$vs. SNAP25 $5^{\Delta / \Delta 3}$ respectively, $\left.\mathrm{P}=0.375\right)$ we performed an oral glucose tolerance test because we hypothesized that the incretin effect, which we bypassed with the IP injection of glucose, might be important for the augmentation of insulin secretion in the SNAP25 $\triangle 3$ mouse. Oral glucose tolerance was again not different between genotypes (Fig. 1C). However as was observed with the IP route of delivery plasma insulin levels were lower in SNAP25 $5^{\Delta 3 / \Delta 3}$ mice after the glucose gavage (Fig. 1D). Given the lower levels of insulin in SNAP25 $5^{\Delta 3 / \Delta 3}$ mice, but a normal glucose tolerance, it would appear that insulin sensitivity is improved in SNAP25 $5^{\Delta 3 / \Delta 3}$.

In order to separate the insulin secretion phenotype from the insulin sensitivity phenotype, we measured $\alpha_{2 A} A R$ dependent inhibition of GSIS from SNAP25 $5^{\Delta 3 / \Delta 3}$ islets ex vivo. It has been previously reported in studies 
using INS-1 832/13 rat insulinoma cells that inhibition of insulin exocytosis by norepinephrine- $\alpha_{2 A} A R$ signaling is mediated by the GBy-SNAP25 interaction (26). Therefore, we also sought to determine whether an $\alpha_{2} A R$ agonist would similarly inhibit insulin secretion in intact islets from SNAP25 $5^{\Delta 3 / \Delta 3}$ mice due to the lack of GßY-SNAP25 interaction.Islets from SNAP25 $5^{\Delta 3 / \Delta 3}$ mice did not have a statistically different alteration in GSIS (Fig. 2A,B). The $\alpha_{2} A R$ selective agonist, brimonidine $(\mathrm{Br})$, inhibited GSIS in a concentration-dependent manner in islets regardless of SNAP25 genotype (Fig. 2C). Insulin content of the islets was also not affected by SNAP25 genotype (Fig. 2D). This indicates that in intact mouse islets, $\alpha_{2 A} A R$-mediated signaling is able to inhibit GSIS via a mechanism that is not dependent upon the GßY-SNAP25 interaction.

Our prior studies suggested that SNAP2 $5^{\Delta 3 / \Delta 3}$ had an altered behavioral response to acute physiological stressors $(5,6)$. We performed calorimetry studies where we assessed energy expenditure and feeding behavior in chow fed male SNAP $25^{+/+}$and SNAP $25^{\Delta 3 / \Delta 3}$ mice at standard housing temperature $\left(22{ }^{\circ} \mathrm{C}\right)$. We also exposed them to an acute cold challenge $\left(6^{\circ} \mathrm{C}\right)$ to assess whether they could mount a physiologic response to a cold stress and to see if they exhibit a normal increase in energy expenditure and food intake. At normal housing temperatures SNAP25 $5^{\Delta 3 / \Delta 3}$ mice had similar rates of energy expenditure (Fig. 3A) and food intake (Fig. 3B), with similar circadian patterns for both variables peaking at the onset of the dark cycle. In response to a decrease in environmental temperature both SNAP25 $5^{\Delta 3 / \Delta 3}$ mice and their SNAP25 $5^{+/+}$littermates mounted a robust increase in energy expenditure. This was also accompanied by an increased duration of feeding activity in SNAP25 $5^{\Delta 3 / \Delta 3}$ mice (Fig. 3E). Cardiovascular parameters were also measured, and no differences were observed in the SNAP2 $5^{\Delta 3 / \Delta 3}$ mice (Supplementary Fig. S1). Thus, on a chow diet SNAP2 $5^{\Delta 3 / \Delta 3}$ mice display subtle changes in feeding behavior that overall does not impact energy balance, and the physiologic response to cold is intact.

Despite having no apparent difference in islet function, SNAP25 $5^{\Delta 3 / \Delta 3}$ mice did appear to have improved insulin sensitivity in the absence of a change in body weight or energy expenditure on a chow diet. It was unclear if the improvement in insulin action would persist in the presence of a high fat diet. Therefore, we placed 8-weekold male and female SNAP25 $5^{+/}$and SNAP25 $23 / \Delta 3$ mice on a HFD (Bio-serv diet, $60 \%$ kcal from fat) for 8 weeks. In both male and female mice, SNAP $25^{+/+}$mice rapidly gained weight on the HFD, whereas SNAP $25^{\Delta 3 / \Delta 3}$ mice were resistant to HFD-induced weight gain (Fig. 4A,E). Body composition analyses over the course of the study revealed that the reduced weight gain in SNAP25 $5^{\Delta 3 / \Delta 3}$ mice was due to reduced adiposity (Fig. 4B,C,F,G). This was confirmed in postmortem analyses of these mice; gonadal fat (epididymal WAT (eWAT) in male and 
periovarian (poWAT) in female), inguinal WAT (iWAT), retroperitoneal WAT (rWAT), and interscapular BAT (iBAT) were all reduced in SNAP25 $5^{\Delta 3 / \Delta 3}$ mice (Fig. 4D,H). Liver weight was reduced only in male SNAP25 $5^{\Delta 3 / \Delta 3}$. We also found no significant difference in fecal triglyceride content, indicating that the reduction in body weight in SNAP25 $23 / \Delta 3$ mice was not due to a decrease in lipid absorption by the gut (Supplementary Fig. S2).

Having observed a profound difference in weight gain and adiposity in SNAP25 $5^{\Delta 3 / \Delta 3}$ mice when challenged with a HFD, we hypothesized that glucose homeostasis would also be improved. Indeed, HFD fed SNAP2 $5^{\Delta 3 / \Delta 3}$ male mice showed a significant improvement in both the IP-GTT (Fig. 5A) and ITT (Fig. 5B) compared with SNAP25 $5^{+/}$mice. SNAP25 $5^{\Delta 3 / \Delta 3}$ male mice had lower fasting glucose levels (Fig. 5C) congruent with their lower IP-GTT and ITT curves. Nevertheless, plasma insulin was also significantly lower (Fig. 5D). Together, these data indicate that there is a bona fide improvement in the insulin sensitivity of the SNAP $25^{\Delta 3 / \Delta 3}$ male mice. Female mice did not gain as much weight in response to HFD as their male counterparts. This likely explains why female SNAP2 $5^{\Delta 3 / \Delta 3}$ mice had a similar glucose (Fig. 5E) and insulin tolerance (Fig. 5F), as well as blood glucose (Fig. 5G) and plasma insulin (Fig. 5H), as their SNAP25 $5^{+/}$littermates. We then decided to investigate feeding behavior in the SNAP2 $5^{\Delta 3 / \Delta 3}$ mouse more thoroughly as the difference in weight gain occurred within the first few weeks on diet. We examined the weekly food intake in mice on HFD for 5 weeks (Fig. 6). During the first two weeks of HFD, SNAP25 $5^{+/}$mice exhibit a robust increase in consumption (which is commonly observed in wild-type mice). However, this was not found in SNAP25 $5^{\Delta 3 / \Delta 3}$ mice. By the third week, the hyperphagia in the SNAP25 $5^{+/}$mice had diminished, and by week 4 the two genotypes began to consume similar amounts of HFD.

These data indicate that SNAP25 $5^{\Delta 3 / \Delta 3}$ mice have a significantly altered food consumption phenotype, which is likely a major contributor towards the reduced weight gain and improved glucose homeostasis. However, the contribution of specific tissues to the improved glucose homeostasis of SNAP $25^{\Delta 3 / \Delta 3}$ mice was unknown. To investigate this we performed hyperinsulinemic euglycemic clamps in chronically catheterized conscious male mice that had been consuming the HFD for 8 weeks ( $27 \pm 2$ vs $39 \pm g$ body weight; SNAP $25^{\Delta 3 / \Delta 3}$ vs. SNAP $25^{+/+}$) to determine if insulin suppression of endogenous (i.e. hepatic) glucose production and/or stimulation of peripheral glucose uptake were altered. The glucose infusion rate required to maintain euglycemia was markedly increased in SNAP25 $5^{\Delta 3 / \Delta 3}$ despite lower clamp insulin concentration (Fig. 7A), with arterial blood glucose maintained at euglycemia in both groups throughout the clamp procedure (Fig. 7A'). Arterial insulin levels were lower in the 
basal period in SNAP25 $5^{\Delta 3 / \Delta 3}(2.5 \pm 0.2 \mathrm{vs}, 5.8 \pm 1.1 \mathrm{ng} / \mathrm{ml})$ and increased during clamp period $(5.1 \pm 0.8 \mathrm{vs} .9 .7 \pm 1.7$ $\mathrm{ng} / \mathrm{ml}$ ) during insulin infusion. Using $\left[3-{ }^{3} \mathrm{H}\right] \mathrm{glucose}$ we determined that the increase in glucose requirements was because of increase in whole body glucose uptake (Fig. 7B). Basal endogenous glucose production as well as insulin suppression of endogenous glucose production were comparable (Fig. 7C). To determine which tissues contributed to the increase in glucose disposal we assessed glucose uptake in multiple tissues during the clamp using $\left[{ }^{14} \mathrm{C}\right] 2$-deoxy-D-glucose (2-DG). 2DG-determined glucose uptake was markedly increased in SNAP25 $5^{\Delta 3 / \Delta 3}$ mice in multiple skeletal muscles (gastrocnemius, soleus, and vastus lateralis) and white adipose tissue depots (perigonadal and inguinal) (Fig. 7D) as well as in heart. Glucose uptake was unchanged in the interscapular brown adipose tissue (iBAT) and brain. Together, these data suggest that multiple tissues of SNAP25 $25^{\Delta 3 / \Delta 3}$ mice take up glucose more readily in response to insulin than SNAP25 $5^{+/+}$mice.

The marked increase in glucose uptake in subcutaneous AT indicated that there may be additional changes to this tissue. We first examined this tissue histologically. The iWAT of SNAP $25^{\Delta 3 / \Delta 3}$ mice had much smaller adipocytes (Fig. 8A). This was especially noticeable in iWAT of female mice. There were also significantly more small multilocular adipocytes that exhibited strong staining for of uncoupling protein 1 (UCP1): the signature marker of brown and beige adipocytes. The morphology of the iBAT from SNAP $25^{\Delta 3 / \Delta 3}$ mice also showed smaller lipid droplets (Fig. 8B). UCP1 staining appeared stronger in the SNAP25 $5^{\Delta 3 / \Delta 3}$ iBAT, but this could be due to the higher density of the adipocytes per visual field. This indicates that SNAP25 $5^{\Delta 3 / \Delta 3}$ mice have improved browning of their subcutaneous WAT, which is likely contributing to the increased glucose uptake in their subcutaneous AT.

We then began to investigate the molecular changes that occurred in the adipose tissue of the SNAP25 $5^{\Delta / \Delta 3}$ mice. Norepinephrine secreted from sympathetic neurons in response to cold is the classical mechanism by which brown adipose tissue (BAT) thermogenesis is triggered and white adipocytes are pushed towards a more brown-like phenotype $(7,27)$. Norepinephrine- $\beta A R$ signaling drives the activation of PKA and thereby the BAT signature protein, UCP1. PKA signaling appeared to be increased as indicated by the greater intensity of bands detected in Western blots using a PKA substrate antibody (Fig. 9) in both the iWAT and gWAT of SNAP25 $5^{\Delta 3 / \Delta 3}$ mice. Note that in SNAP25 $5^{+/+}$mice the HFD tended to suppress many of these phosphoproteins, but, importantly, they were largely preserved in the SNAP25 $5^{\Delta 3 / \Delta 3}$ mice, particularly in the iWAT. This was associated with an increase in mitochondrial proteins and markers of lipolytic including adipose triglyceride lipase 
(ATGL). HFD feeding also reduced these markers, most prominently in SNAP25 $5^{++}$mice, while in HFD fed SNAP $25^{\Delta 3 / \Delta 3}$ mice these markers were similar to those of mice fed a chow diet. These changes are consistent with a scenario of increased norepinephrine release from the neurons that innervate the iWAT and gWAT depots. In the iBAT there were few changes observed in response to either genotype or diet.

\section{Discussion}

Hormones that signal through GPCRs have long been known to be important modulators of signals and cell types that impact type 2 diabetes (28), since they are regulators of GSIS (29-31), feeding behavior (32), gastrointestinal biology (33), and adipocyte lipolysis and thermogenesis (34). This signaling has most often been attributed to receptor-driven activation of $\mathrm{Ga}$ subunits engaging their intracellular effectors. Here, we demonstrate that signaling through the Gßy subunits that regulate exocytosis by interacting with the SNARE complex have important physiological consequences on feeding behavior and adipocyte thermogenesis. By utilizing a mouse model that lacks the last three amino acids of SNAP25, we have been able to investigate the role of GßY-inhibition of SNAP25-mediated vesicle release on glucose handling and energy balance. While the mechanism in the various cell types that may be responsible for this will require further in-depth investigation, these finding may have therapeutic importance for metabolic diseases such as obesity and type 2 diabetes, since targeting of G $\beta y$-mediated signaling has yet to be exploited for these diseases.

We predicted that the SNAP25 $23 / \Delta 3$ mice would exhibit improved GSIS because GßY is a regulator of insulin exocytosis $(22,35)$. Instead, we found that there is no difference in GSIS in islets from SNAP25 $5^{\Delta 3 / \Delta 3}$ mice. Furthermore, $\alpha_{2}$ AR-mediated inhibition of GSIS was unaltered. In addition to these ex vivo studies, we examined GSIS in vivo. Contrary to our expectations, in vivo GSIS actually was reduced. This led us to hypothesize that SNAP25 $5^{\Delta / \Delta 3}$ mice have improved insulin-dependent glucose uptake so we conducted a series of studies to determine if these mice had alterations in their energy homeostasis.

In our prior work we observed that SNAP25 $5^{\Delta 3 / \Delta 3}$ have behavioral deficits that impact learning, memory, and the response to stressors $(5,6)$. We asked whether similar deficits could impact energy homeostasis. Using the Promethion comprehensive calorimetry system we monitored energy expenditure and feeding behavior in chow fed SNAP25 $5^{\Delta / \Delta 3}$ and their SNAP25 $5^{+/}$litter mates. We found that overall energy expenditure and food intake was unremarkable. We then metabolically challenged these mice with cold exposure. They were able to mount a robust increase in exergy expenditure and food intake in response to this metabolic stressor. Thus, 
bioRxiv preprint doi: https://doi.org/10.1101/2020.04.29.069138; this version posted April 30, 2020. The copyright holder for this preprint (which

was not certified by peer review) is the author/funder, who has granted bioRxiv a license to display the preprint in perpetuity. It is made available under aCC-BY-NC-ND 4.0 International license.

while SNAP25 $23 / \Delta 3$ have some behavioral deficits it does not seem to negatively impact maintenance of metabolism.

In the present studies, we found that SNAP $25^{\Delta 3 / \Delta 3}$ mice were remarkably resistant to weight gain when challenged with a HFD. We first asked if this phenotype was driven by alterations in energy intake. In SNAP25 $5^{\Delta 3 / \Delta 3}$ mice, the initial hyperphagia seen in wild type mice to a HFD was absent. After 2 weeks the hyperphagia is less robust in the SNAP $25^{+/+}$mice and the food of intake gradually matches of SNAP2 $25^{\Delta 3 / \Delta 3}$ mice, The lack of the hyperphagia may reflect a neophobia of the novel food, disliking it only because it is different than what they are used to eating. This delay in augmenting caloric intake sets these mice up on a different weight gain trajectory that persists throughout the study. There was no alteration in gut absorption of dietary triglycerides indicating that feeding behavior was the sole alteration in energy intake.

SNAP25 $5^{\Delta 3 / \Delta 3}$ mice have marked improvement in glucose homeostasis. Our initial hypothesis was that this would be present because an improvement in insulin secretion as SNAP25 has been show to transduce signals that inhibit insulin secretion (13-15). In fact, we found that SNAP25 $5^{\Delta 3 / \Delta 3}$ mice have normal $\beta$-cell function and the improvement in glucose homeostasis is because of an improvement in insulin action. This improvement was observed on a chow diet, but this benefit was most evident when animals were presented with a HFD. The protection from weight gain on a HFD synergized with the underlying metabolic protection to lead to robust metabolic protection. The sites of this improvement was evident from clamp studies. We saw marked improvement in glucose uptake in skeletal muscle and white adipose tissue. The improvement in inguinal white adipose tissue was profound (a 4-fold increase).

If this temporary reduction in caloric intake was the sole driver of the lean phenotype, then we would expect the body weights to remain parallel. Instead, they continue to diverge suggesting that the lean phenotype of SNAP25 $5^{\Delta 3 / \Delta 3}$ mice may be more complicated. Studies utilizing a radiolabeled glucose tracer showed that SNAP25 $5^{\Delta 3 / \Delta 3}$ mice have a marked increased glucose uptake in adipose tissue. Upon closer evaluation of the adipose tissue, it was found that SNAP25 $5^{\Delta 3 / \Delta 3}$ mice have increased browning of their white adipose tissue. This browning corresponded with increased PKA signaling in SNAP25 ${ }^{\Delta 3 / \Delta 3}$ adipose tissue. We hypothesize that increased sympathetic tone from the SNAP2 $5^{\Delta 3 / \Delta 3}$ neurons innervating the WAT is driving the enhanced PKA signaling and thermogenic marker expression, though we cannot rule out the possibility of other hormones contributing to this effect. It has recently been appreciated that adult humans possess significant amounts of 
brown adipocytes that are rich in mitochondria and UCP1 (36-39), and the activation of adipocyte thermogenesis is now seen as an attractive therapeutic target for obesity and metabolic disease. In humans adipose tissue, the $\beta_{1} A R$ is more important than the $\beta_{3} A R$ for the regulation of metabolism (40). Inhibiting the G $\beta y-S N A P 25$ interaction to stimulate endogenous catecholamine release in the adipose tissue, instead of pharmacologically targeting the $\beta A R s$ directly, may be a way to circumvent the side effects of $\beta_{1} A R$ agonists.

These findings highlight the importance of the GßY-SNAP25 interaction in the regulation of body weight and glycemic control. Though we did not observe the augmentation of GSIS that we predicted, we did find that SNAP25 $5^{\Delta / \Delta 3}$ mice have beneficial metabolic effects in adipose tissue, skeletal muscle, and feeding behavior. Importantly, there are also no apparent cardiovascular effects in these mice which could have limited the therapeutic relevance of targeting this pathway. Nevertheless, these studies are limited in their ability to determine how these beneficial metabolic effects occur. Tissue specific gene knock-in of SNAP25 $\Delta 3$ will be invaluable to further understand the processes behind these metabolic changes. While there are many pathways that may be targeted to increase adipose tissue metabolism and energy expenditure, these signaling pathways are also heavily involved in various physiological processes in other tissues which constrains their clinical utility (34). Pharmacological targeting of the GßY-SNAP25 interaction may be a therapeutic alternative to directly targeting the GPCRs because SNAP25 $23 / \Delta 3$ mice have improvements in food intake, activity, and adipose browning, all without significant side effects.

\section{Materials and Methods}

\section{$\underline{\text { Animal procedures }}$}

Mice used for these experiments were generated from heterozygous breeding of SNAP $25^{+/ \Delta 3}$ mice on a C57BL/6 background. The strategy for the generation of these mice was previously described (5). Mice were maintained ad libitum on chow, Laboratory Rodent Diet 5001 (LabDiet), unless otherwise stated. Mice were maintained on a 12-hour light, 12-hour dark cycle and housed with 3-5 animals per cage. All procedures were approved by the Institutional Animal Care and Use Committee at Vanderbilt University

\section{$\underline{\text { HFD feeding }}$}

SNAP $25^{+/+}$and SNAP25 $5^{\Delta 3 / \Delta 3}$ mice were placed on a HFD $(60 \%$ calories from fat and $36 \%$ fat by weight,

3282; Bio-Serv). Throughout the course of the study, body composition of live mice was measured by pulsed 
NMR with Minispec Model mq7.5 (Bruker Instruments). Mice were euthanized by isoflurane overdose at the end of the study for collection of tissues.

Glucose tolerance tests (GTTs) and insulin tolerance tests (ITTs)

For all tolerance tests, mice were fasted for 5 hours, and fasting blood glucose was measured from a drop of tail vein blood with a Bayer CONTOUR glucometer and glucose test strips at the indicated time points. For GTTs in figure 1, separate cohorts of mice were given either an intraperitoneal (IP) injection or oral gavage of $2.0 \mathrm{~g} / \mathrm{kg}$ glucose. Insulin content was analyzed in duplicate by RIA by Vanderbilt University Hormone Assay and Analytical Services Core.

For tolerance tests in figure 5, mice were given IP injections of $1.0 \mathrm{~g} / \mathrm{kg}$ dextrose (Agri Laboratories, Ltd.) in $0.9 \%$ saline (Hospira, Inc.) at 22 weeks of age and an IP injection of $0.5 \mathrm{U} / \mathrm{kg}$ insulin (Humulin R, Lilly USA) in $0.9 \%$ saline (Hospira, Inc.) at 23 weeks of age. Mice were fasted for five hours and blood glucose was collected from the tail vein after which the mice were subsequently euthanized by $\mathrm{CO}_{2}$. Blood was collected into EDTA coated tubes via cardiac puncture and plasma insulin was measured by ELISA (Mercodia).

\section{Mouse islet perifusion}

Pancreatic islets were isolated and perifusion assays were performed on fresh islets at the Vanderbilt Islet Procurement and Analysis Core as previously described (PMID: 22167125). Islet preparations were equilibrated and stable baseline response established at $5.6 \mathrm{mmol} / \mathrm{L}$ glucose, and insulin secretion was stimulated with $16.7 \mathrm{mmol} / \mathrm{L}$ glucose.

\section{Energy balance}

Energy balance studies were performed on chow-fed, male mice in a Promethion system (Sable Systems International) by the Vanderbilt Mouse Metabolic Phenotyping Center.

\section{$\underline{\text { Cardiovascular imaging }}$}

Cardiac parameters, as measured by parasternal M-mode echocardiography103 were collected. Mice had their chest fur shaved and a topical depilatory agent was used to remove any remaining fur in the area. Ultrasound coupling gel heated to $34^{\circ} \mathrm{C}$ was applied to the chest area and a linear array transducer $(18-23 \mathrm{MHz})$ was positioned to obtain two-dimensional B-mode parasternal long and short axis views at the mid-ventricular level (Vevo 2100, VisualSonics). One-dimensional M-mode images were obtained for measurement in the short axis view to obtain cardiac wall thickness and chamber dimensions. Left ventricular (LV) chamber size and wall 
thickness were measured off-line in the M-mode from at least three consecutive beats and averaged. LV wall thickness: intraventricular septum (IVS) and posterior wall (PW) at systole and diastole; and LV internal dimensions (LVID) during systole and diastole were measured.

\section{Hyperinsulinemic euglycemic clamps}

Clamp studies were done chronically catheterized (carotid artery and jugular vein) conscious mice. Catheters were inserted 4-5 days prior to a study by the Metabolic Pathophysiology Core (41-43). In chronically catheterized mice $\left[{ }^{3-}{ }^{3} \mathrm{H}\right]$ glucose was used to measure whole body basal and clamp glucose flux. A $4 \mathrm{mU} \cdot \mathrm{kg}^{-1} \cdot \mathrm{min}^{-1}$ insulin infusion will be initiated to increase insulin to a physiologic range. Red blood cells from a donor animal are infused at a constant rate to replace blood taken during study. Basal and clamp period blood samples for glucose, insulin and tracer. At the end of the clamp period, multiple tissues were collected to measure the accumulation of ${ }^{14} \mathrm{C} 2 \mathrm{DG}$. Using tracer methods $\left[3-{ }^{3} \mathrm{H}\right]$ glucose and ${ }^{14} \mathrm{CDG}$ during the clamp, we assessed tissue glucose uptake (44) and whole body (and hepatic) glucose flux $(45,46)$.

Histology

Adipose tissues were fixed with were fixed in $10 \%$ formaldehyde overnight and subsequently stored in $70 \%$ ethanol then processed routinely, embedded, sectioned and stained with hematoxylin and eosin $(\mathrm{H} \& \mathrm{E})$ or immunohistochemical stained for UCP1 (ab10983, Abcam). Histology was performed by the Vanderbilt Translational Pathology Shared Resource. Slides were imaged at 20× with a Leica SCN400 Slide Scanner by the Vanderbilt Digital Histology Shared Resource.

\section{Western blotting}

Adipose tissues were lysed and sonicated in a buffer containing 25 mM HEPES (pH 7.4), 150 mM NaCL, $5 \mathrm{mM}$ EDTA, $5 \mathrm{mM}$ EGTA, $5 \mathrm{mM}$ glycerophosphate, $0.9 \%$ Triton X-100, 0.1\% IGEPAL, $5 \mathrm{mM}$ sodium pyrophosphate, $10 \%$ glycerol, plus 1 tablet each of cOmplete ${ }^{\mathrm{TM}}$ protease inhibitor cocktail (04693124001, Roche) and PhoSTOP phosphatase inhibitors (04906845001, Roche) per $10 \mathrm{ml}$ of lysis buffer. The lysates of 40 $\mu \mathrm{g}$ total protein were resolved in $10 \%$ Tris-glycine gels, transferred to nitrocellulose membranes, which were incubated overnight at $4^{\circ} \mathrm{C}$ with specific primary antibodies, followed by secondary antibody incubations for $1 \mathrm{~h}$ at room temperature. Image acquisition was performed on Bio-Rad digital ChemiDoc MP with IR.

The following Antibodies were purchased from Cell Signaling Technology (Danvers, MA): anti-ACLY (dilution 1:1000, \#4332), anti-aP2 (1:1000, \#2120), Anti-ATGL (1:1000, \#2439), anti-CoxIV (1:1000, \#4844), anti- 
bioRxiv preprint doi: https://doi.org/10.1101/2020.04.29.069138; this version posted April 30, 2020. The copyright holder for this preprint (which

was not certified by peer review) is the author/funder, who has granted bioRxiv a license to display the preprint in perpetuity. It is made available under aCC-BY-NC-ND 4.0 International license.

HSL (1:1000, \#4107), PKA substrate (1:1000, \#9624), and $\beta$-actin (1:2000, \#4967). Total OXPHOS Rodent WB antibody cocktail (1:1000, MS604-300) was from Abcam (Cambridge, MA). Secondary antibodies anti-rabbit (1:20000, A3687) and anti-mouse (1:20000, A3562) were obtained from MilliporeSigma (Burlington, MA).

\section{$\underline{\text { Statistics }}$}

Data are mean \pm SEM, using GraphPad Prism version 8.3.1 for Windows 64-bit (GraphPad Software). Analysis comparing genotype only were performed with an unpaired t-test. Analysis comparing genotype along with time, light/dark cycle, or +/- clamp, were performed with a two-way ANOVA or a mixed-effects model if data were missing. Multiple comparison tests were performed with the Bonferroni correction for SNAP25 genotype only and are indicated on figures by asterisks corresponding to ${ }^{*}, \mathrm{P}<.05 ;{ }^{* *}, \mathrm{P}<.01 ;{ }^{* *}, \mathrm{P}<.001$. 
bioRxiv preprint doi: https://doi.org/10.1101/2020.04.29.069138; this version posted April 30, 2020. The copyright holder for this preprint (which was not certified by peer review) is the author/funder, who has granted bioRxiv a license to display the preprint in perpetuity. It is made available under aCC-BY-NC-ND 4.0 International license.

\section{References}

1. Sriram K, Insel PA. G Protein-Coupled Receptors as Targets for Approved Drugs: How Many Targets and How Many Drugs? Mol Pharmacol. 2018;93(4):251-8. Epub 2018/01/03. doi: 10.1124/mol.117.111062. PubMed PMID: 29298813; PMCID: PMC5820538.

2. Campbell AP, Smrcka AV. Targeting G protein-coupled receptor signalling by blocking G proteins. Nat Rev Drug Discov. 2018;17(11):789-803. Epub 2018/09/28. doi: 10.1038/nrd.2018.135. PubMed PMID: 30262890; PMCID: PMC6409483.

3. Zurawski Z, Yim YY, Alford S, Hamm HE. The expanding roles and mechanisms of G protein-mediated presynaptic inhibition. J Biol Chem. 2019;294(5):1661-70. doi: 10.1074/jbc.TM118.004163. PubMed PMID: 30710014; PMCID: PMC6364771.

4. Zurawski Z, Rodriguez S, Hyde K, Alford S, Hamm HE. Gßy Binds to the Extreme C Terminus of SNAP25 to Mediate the Action of Gi/o-Coupled G Protein-Coupled Receptors. Mol Pharmacol. 2016;89(1):7583. Epub 2015/10/30. doi: 10.1124/mol.115.101600. PubMed PMID: 26519224; PMCID: PMC4702098.

5. Zurawski Z, Thompson Gray AD, Brady LJ, Page B, Church E, Harris NA, Dohn MR, Yim YY, Hyde K, Mortlock DP, Jones CK, Winder DG, Alford S, Hamm HE. Disabling the GßY-SNARE interaction disrupts GPCR-mediated presynaptic inhibition, leading to physiological and behavioral phenotypes. Science signaling. 2019;12(569). Epub 2019/02/19. doi: 10.1126/scisignal.aat8595. PubMed PMID: 30783011.

6. Irfan M, Zurawski Z, Hamm HE, Bark C, Stanton PK. Disabling GßY-SNAP-25 interaction in genetargeted mice results in enhancement of long-term potentiation at Schaffer collateral-CA1 synapses in the hippocampus. Neuroreport. 2019;30(10):695-9. doi: 10.1097/WNR.0000000000001258. PubMed PMID: 31095110.

7. Bartness TJ, Vaughan $\mathrm{CH}$, Song CK. Sympathetic and sensory innervation of brown adipose tissue. Int J Obes (Lond). 2010;34 Suppl 1:S36-42. doi: 10.1038/ijo.2010.182. PubMed PMID: 20935665; PMCID: PMC3999344.

8. Kenny PJ. Reward mechanisms in obesity: new insights and future directions. Neuron. 2011;69(4):66479. doi: 10.1016/j.neuron.2011.02.016. PubMed PMID: 21338878; PMCID: PMC3057652.

9. Williams KW, Elmquist JK. From neuroanatomy to behavior: central integration of peripheral signals regulating feeding behavior. Nature neuroscience. 2012;15(10):1350-5. Epub 2012/09/25. doi:

10.1038/nn.3217. PubMed PMID: 23007190; PMCID: PMC3763714.

10. Morrison SF, Madden CJ, Tupone D. Central neural regulation of brown adipose tissue thermogenesis and energy expenditure. Cell Metab. 2014;19(5):741-56. Epub 2014/03/19. doi: 10.1016/j.cmet.2014.02.007. PubMed PMID: 24630813; PMCID: 4016184.

11. Kim KS, Seeley RJ, Sandoval DA. Signalling from the periphery to the brain that regulates energy homeostasis. Nat Rev Neurosci. 2018;19(4):185-96. Epub 2018/02/22. doi: 10.1038/nrn.2018.8. PubMed PMID: 29467468.

12. Vercruysse P, Vieau D, Blum D, Petersén A, Dupuis L. Hypothalamic Alterations in Neurodegenerative Diseases and Their Relation to Abnormal Energy Metabolism. Frontiers in molecular neuroscience. 2018;11:2. Epub 2018/01/19. doi: 10.3389/fnmol.2018.00002. PubMed PMID: 29403354; PMCID: PMC5780436.

13. Gaisano HY. Recent new insights into the role of SNARE and associated proteins in insulin granule exocytosis. Diabetes Obes Metab. 2017;19 Suppl 1:115-23. doi: 10.1111/dom.13001. PubMed PMID: 28880475.

14. Xiong QY, Yu C, Zhang Y, Ling L, Wang L, Gao JL. Key proteins involved in insulin vesicle exocytosis and secretion. Biomed Rep. 2017;6(2):134-9. Epub 2017/01/10. doi: 10.3892/br.2017.839. PubMed PMID: 28357064; PMCID: PMC5351265.

15. Thurmond DC, Gaisano HY. Recent Insights into Beta-cell Exocytosis in Type 2 Diabetes. J Mol Biol. 2020;432(5):1310-25. Epub 2019/12/19. doi: 10.1016/j.jmb.2019.12.012. PubMed PMID: 31863749. 16. Hird TR, Zomer E, Owen A, Chen L, Ademi Z, Magliano DJ, Liew D. The impact of diabetes on productivity in China. Diabetologia. 2019;62(7):1195-203. Epub 2019/04/27. doi: 10.1007/s00125-019-4875-4. PubMed PMID: 31030220.

17. Dall TM, Yang W, Gillespie K, Mocarski M, Byrne E, Cintina I, Beronja K, Semilla AP, lacobucci W, Hogan PF. The Economic Burden of Elevated Blood Glucose Levels in 2017: Diagnosed and Undiagnosed Diabetes, Gestational Diabetes Mellitus, and Prediabetes. Diabetes Care. 2019;42(9):1661-8. Epub 2019/04/02. doi: 10.2337/dc18-1226. PubMed PMID: 30940641; PMCID: PMC6702607. 
bioRxiv preprint doi: https://doi.org/10.1101/2020.04.29.069138; this version posted April 30, 2020. The copyright holder for this preprint (which was not certified by peer review) is the author/funder, who has granted bioRxiv a license to display the preprint in perpetuity. It is made available under aCC-BY-NC-ND 4.0 International license.

18. Shrestha SS, Honeycutt AA, Yang W, Zhang P, Khavjou OA, Poehler DC, Neuwahl SJ, Hoerger TJ. Economic Costs Attributable to Diabetes in Each U.S. State. Diabetes Care. 2018;41(12):2526-34. Epub 2018/10/10. doi: 10.2337/dc18-1179. PubMed PMID: 30305349.

19. American Diabetes Association. Economic Costs of Diabetes in the U.S. in 2017. Diabetes Care. 2018;41(5):917-28. Epub 2018/03/22. doi: 10.2337/dci18-0007. PubMed PMID: 29567642; PMCID: PMC5911784.

20. Tremmel M, Gerdtham UG, Nilsson PM, Saha S. Economic Burden of Obesity: A Systematic Literature Review. Int J Environ Res Public Health. 2017;14(4). Epub 2017/04/19. doi: 10.3390/ijerph14040435. PubMed PMID: 28422077; PMCID: PMC5409636.

21. Nauck MA, Meier JJ. Incretin hormones: Their role in health and disease. Diabetes Obes Metab. 2018;20 Suppl 1:5-21. doi: 10.1111/dom.13129. PubMed PMID: 29364588.

22. Zhao Y, Fang Q, Straub SG, Lindau M, Sharp GWG. Noradrenaline inhibits exocytosis via the G protein $\beta y$ subunit and refilling of the readily releasable granule pool via the $\alpha_{i 1 / 2}$ subunit. J Physiol. 2010;588(Pt 18):3485-98. Epub 2010/07/21. doi: jphysiol.2010.190090 [pii]

10.1113/jphysiol.2010.190090. PubMed PMID: 20643776; PMCID: 2988513.

23. Schelbert KB. Comorbidities of obesity. Prim Care. 2009;36(2):271-85. doi: 10.1016/j.pop.2009.01.009. PubMed PMID: 19501243.

24. Martin-Rodriguez E, Guillen-Grima F, Martí A, Brugos-Larumbe A. Comorbidity associated with obesity in a large population: The APNA study. Obes Res Clin Pract. 2015;9(5):435-47. Epub 2015/05/13. doi: 10.1016/j.orcp.2015.04.003. PubMed PMID: 25979684.

25. Ng M, Fleming T, Robinson M, Thomson B, Graetz N, Margono C, Mullany EC, Biryukov S, Abbafati C, Abera SF, Abraham JP, Abu-Rmeileh NME, Achoki T, AlBuhairan FS, Alemu ZA, Alfonso R, Ali MK, Ali R, Guzman NA, Ammar W, Anwari P, Banerjee A, Barquera S, Basu S, Bennett DA, Bhutta Z, Blore J, Cabral N, Nonato IC, Chang J-C, Chowdhury R, Courville KJ, Criqui MH, Cundiff DK, Dabhadkar KC, Dandona L, Davis A, Dayama A, Dharmaratne SD, Ding EL, Durrani AM, Esteghamati A, Farzadfar F, Fay DF, Feigin VL, Flaxman A, Forouzanfar MH, Goto A, Green MA, Gupta R, Hafezi-Nejad N, Hankey GJ, Harewood HC, Havmoeller R, Hay S, Hernandez L, Husseini A, Idrisov BT, Ikeda N, Islami F, Jahangir E, Jassal SK, Jee SH, Jeffreys M, Jonas JB, Kabagambe EK, Khalifa SE, Kengne AP, Khader YS, Khang Y-H, Kim D, Kimokoti RW, Kinge JM, Kokubo Y, Kosen S, Kwan G, Lai T, Leinsalu M, Li Y, Liang X, Liu S, Logroscino G, Lotufo PA, Lu Y, Ma J, Mainoo NK, Mensah GA, Merriman TR, Mokdad AH, Moschandreas J, Naghavi M, Naheed A, Nand D, Narayan KMV, Nelson EL, Neuhouser ML, Nisar MI, Ohkubo T, Oti SO, Pedroza A, Prabhakaran D, Roy N, Sampson U, Seo H, Sepanlou SG, Shibuya K, Shiri R, Shiue I, Singh GM, Singh JA, Skirbekk V, Stapelberg NJ, Sturua L, Sykes BL, Tobias M, Tran BX, Trasande L, Toyoshima H, van de Vijver S, Vasankari TJ, Veerman JL, Velasquez-Melendez G, Vlassov VV, Vollset SE, Vos T, Wang C, Wang X, Weiderpass E, Werdecker A, Wright JL, Yang YC, Yatsuya H, Yoon J, Yoon S-J, Zhao Y, Zhou M, Zhu S, Lopez AD, Murray CJ, Gakidou E. Global, regional, and national prevalence of overweight and obesity in children and adults during 1980-2013: a systematic analysis for the Global Burden of Disease Study 2013. Lancet. 2014;384(9945):766-81. Epub 2014/06/02. doi: 10.1016/S0140-6736(14)60460-8. PubMed PMID: 24880830; PMCID: 4624264.

26. Zhao Y, Fang Q, Straub SG, Lindau M, Sharp GWG. Noradrenaline inhibits exocytosis via the G protein bg subunit and refilling of the readily releasable granule pool via the $a_{i} 1 / 2$ subunit. The Journal of physiology. 2010;588(18):3485-98. doi: 10.1113/jphysiol.2010.190090.

27. Schönbaum E, Steiner G, Sellers EA. Brown adipose tissue and norepinephrine. In: Lindberg O, editor. Brown adipose tissue. New York: American Elsevier Publishing Co, Inc.; 1970. p. 179-94.

28. Riddy DM, Delerive P, Summers RJ, Sexton PM, Langmead CJ. G Protein-Coupled Receptors Targeting Insulin Resistance, Obesity, and Type 2 Diabetes Mellitus. Pharmacological reviews. 2018;70(1):3967. doi: 10.1124/pr.117.014373. PubMed PMID: 29233848.

29. Winzell MS, Ahrén B. G-protein-coupled receptors and islet function-implications for treatment of type 2 diabetes. Pharmacol Ther. 2007;116(3):437-48. Epub 2007/09/29. doi: S0163-7258(07)00159-3 [pii]

10.1016/j.pharmthera.2007.08.002. PubMed PMID: 17900700.

30. Ahrén B. Islet $\mathrm{G}$ protein-coupled receptors as potential targets for treatment of type 2 diabetes. Nat Rev Drug Discov. 2009;8(5):369-85. Epub 2009/04/15. doi: nrd2782 [pii]

10.1038/nrd2782. PubMed PMID: 19365392. 
bioRxiv preprint doi: https://doi.org/10.1101/2020.04.29.069138; this version posted April 30, 2020. The copyright holder for this preprint (which was not certified by peer review) is the author/funder, who has granted bioRxiv a license to display the preprint in perpetuity. It is made available under aCC-BY-NC-ND 4.0 International license.

31. Amisten S, Salehi A, Rorsman P, Jones PM, Persaud SJ. An atlas and functional analysis of G-protein coupled receptors in human islets of Langerhans. Pharmacol Ther. 2013;139(3):359-91. Epub 2013/05/18. doi: 10.1016/j.pharmthera.2013.05.004. PubMed PMID: 23694765.

32. Ericson MD, Haskell-Luevano C. A Review of Single-Nucleotide Polymorphisms in Orexigenic Neuropeptides Targeting G Protein-Coupled Receptors. ACS Chem Neurosci. 2018;9(6):1235-46. Epub 2018/05/11. doi: 10.1021/acschemneuro.8b00151. PubMed PMID: 29714060; PMCID: PMC6042215.

33. Canals M, Poole DP, Veldhuis NA, Schmidt BL, Bunnett NW. G-Protein-Coupled Receptors Are Dynamic Regulators of Digestion and Targets for Digestive Diseases. Gastroenterology. 2019;156(6):1600-16. Epub 2019/02/13. doi: 10.1053/j.gastro.2019.01.266. PubMed PMID: 30771352; PMCID: PMC6508858.

34. Ceddia RP, Collins S. A compendium of G-protein-coupled receptors and cyclic nucleotide regulation of adipose tissue metabolism and energy expenditure. Clinical science. 2020;134(5):473-512. doi: 10.1042/cs20190579. PubMed PMID: 32149342.

35. Zhang H, Yasrebi-Nejad H, Lang J. G-protein $\beta y$-binding domains regulate insulin exocytosis in clonal pancreatic $\beta$-cells. FEBS Lett. 1998;424(3):202-6. Epub 1998/04/16. doi: S0014-5793(98)00176-8 [pii]. PubMed PMID: 9539151.

36. van Marken Lichtenbelt WD, Vanhommerig JW, Smulders NM, Drossaerts JMAFL, Kemerink GJ, Bouvy ND, Schrauwen P, Teule GJJ. Cold-activated brown adipose tissue in healthy men. The New England journal of medicine. 2009;360(15):1500-8. Epub 2009/04/10. doi: 10.1056/NEJMoa0808718. PubMed PMID: 19357405.

37. Cypess AM, Lehman S, Williams G, Tal I, Rodman D, Goldfine AB, Kuo FC, Palmer EL, Tseng Y-H, Doria A, Kolodny GM, Kahn CR. Identification and importance of brown adipose tissue in adult humans. The New England journal of medicine. 2009;360(15):1509-17. Epub 2009/04/10. doi: 10.1056/NEJMoa0810780. PubMed PMID: 19357406; PMCID: 2859951.

38. Virtanen KA, Lidell ME, Orava J, Heglind M, Westergren R, Niemi T, Taittonen M, Laine J, Savisto N-J, Enerbäck S, Nuutila P. Functional brown adipose tissue in healthy adults. The New England journal of medicine. 2009;360(15):1518-25. Epub 2009/04/10. doi: 10.1056/NEJMoa0808949. PubMed PMID: 19357407. 39. Yoneshiro T, Aita S, Matsushita M, Kameya T, Nakada K, Kawai Y, Saito M. Brown adipose tissue, whole-body energy expenditure, and thermogenesis in healthy adult men. Obesity (Silver Spring). 2011;19(1):13-6. Epub 2010/05/06. doi: 10.1038/oby.2010.105. PubMed PMID: 20448535.

40. Riis-Vestergaard MJ, Richelsen B, Bruun JM, Li W, Hansen JB, Pedersen SB. Beta-1 and not beta-3adrenergic receptors may be the primary regulator of human brown adipocyte metabolism. J Clin Endocrinol Metab. 2019. Epub 2019/12/23. doi: 10.1210/clinem/dgz298. PubMed PMID: 31867674.

41. Ayala JE, Bracy DP, Malabanan C, James FD, Ansari T, Fueger PT, McGuinness OP, Wasserman DH. Hyperinsulinemic-euglycemic Clamps in Conscious, Unrestrained Mice. J Vis Exp. 2011:e3188. Epub 2011. doi: doi:10.3791/3188; PMCID: 3308587.

42. Chueh FY, Malabanan C, McGuinness OP. Impact of portal glucose delivery on glucose metabolism in conscious, unrestrained mice. Am J Physiol Endocrinol Metab. 2006;291(6):E1206-11. PubMed PMID: 16822956.

43. Benhamed F, Denechaud PD, Lemoine M, Robichon C, Moldes M, Bertrand-Michel J, Ratziu V, Serfaty L, Housset C, Capeau J, Girard J, Guillou H, Postic C. The lipogenic transcription factor ChREBP dissociates hepatic steatosis from insulin resistance in mice and humans. J Clin Invest. 2012;122(6):2176-94. Epub 2012/05/02. doi: 10.1172/jci41636. PubMed PMID: 22546860; PMCID: 3366390.

44. Kraegen EW, James $D E$, Jenkins $A B$, Chisholm DJ. Dose-response curves for in vivo insulin sensitivity in individual tissues in rats. The American journal of physiology. 1985;248(3 Pt 1):E353-62. PubMed PMID: 3883806.

45. Steele R, Wall JS, De Bodo RC, Altszuler N. Measurement of size and turnover rate of body glucose pool by the isotope dilution method. Am J Physiol. 1956;187(1):15-24. Epub 1956/10/01. PubMed PMID: 13362583.

46. Finegood DT, Bergman RN, Vranic M. Estimation of endogenous glucose production during hyperinsulinemic-euglycemic glucose clamps. Comparison of unlabeled and labeled exogenous glucose infusates. Diabetes. 1987;36(8):914-24. PubMed PMID: 3297886. 

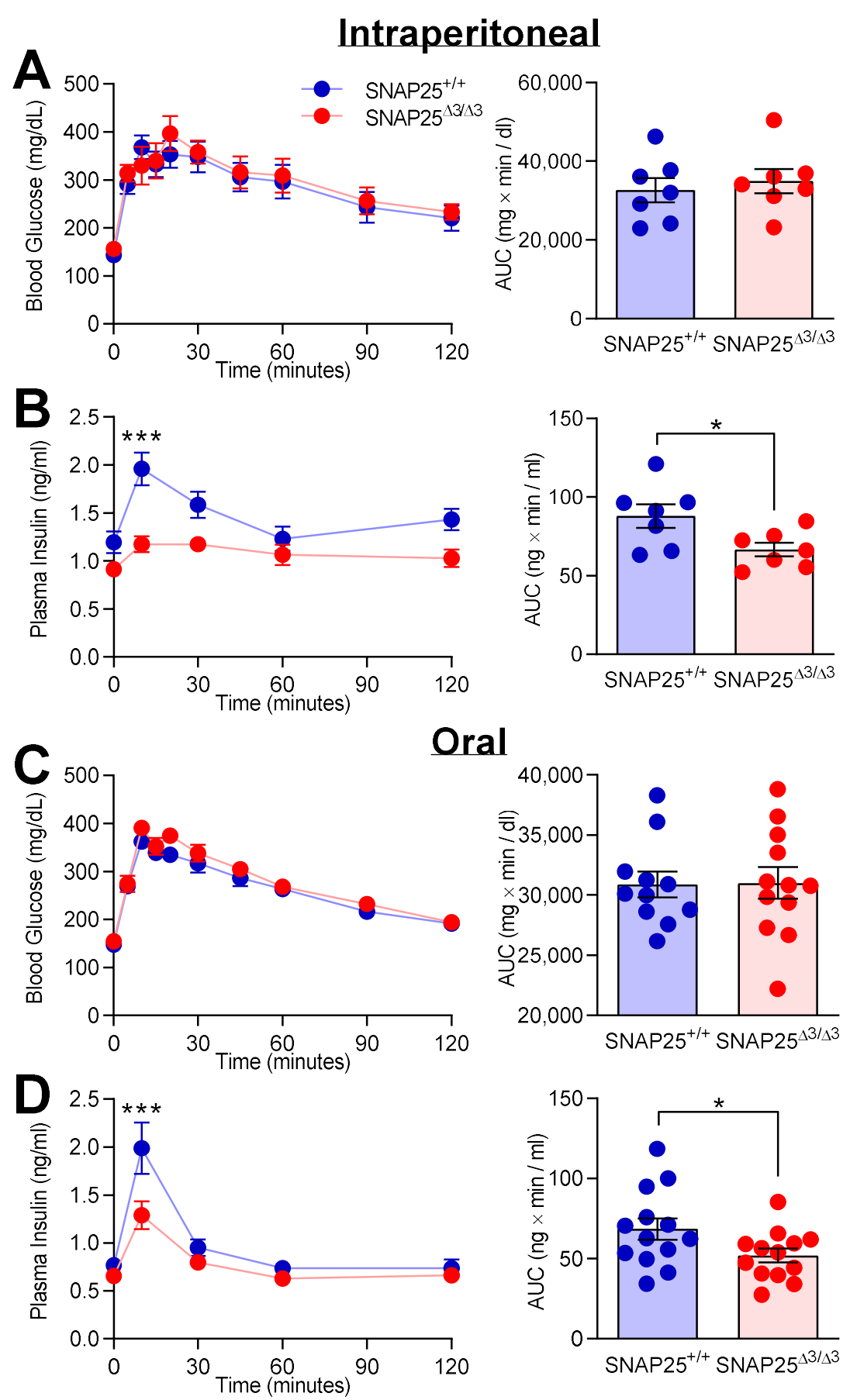

Figure 1: SNAP25 ${ }^{\Delta 3 / \Delta 3}$ mice have normal glucose tolerance but secrete less insulin

A. Glucose tolerance was assessed by an IP-GTT in chow-fed male SNAP25 $25^{+/+}$and SNAP $25^{\Delta 3 / \Delta 3}$ mice at 14 weeks of age. B. Insulin secretion during the IP-GTT revealed that SNAP25 ${ }^{\Delta 3 / \Delta 3}$ mice have reduced plasma insulin in response to glucose challenge $(P=0.0176$ for the effect of genotype, $P=0.0031$ for the effect of interaction). For A and B, $n=8$ SNAP25 $5^{+/}$and $n=8$ SNAP25 $5^{\Delta / \Delta 3}$. C. Glucose tolerance was assessed by an oral GTT in chow-fed male SNAP25 $5^{+/+}$and SNAP2 $5^{\Delta 3 / \Delta 3}$ mice at 15 weeks of age. D. Insulin secretion during the oral GTT revealed that SNAP25 ${ }^{\Delta 3 / \Delta 3}$ mice have reduced plasma insulin in response to glucose challenge $(P=0.073$ for the effect of genotype, $P=0.0009$ for the effect of interaction). For $C$ and $D, n=13$ SNAP2 $5^{+/+}$and $n=13$ SNAP25 $5^{\Delta 3 / \Delta 3}$. Values are expressed as mean \pm SEM. 

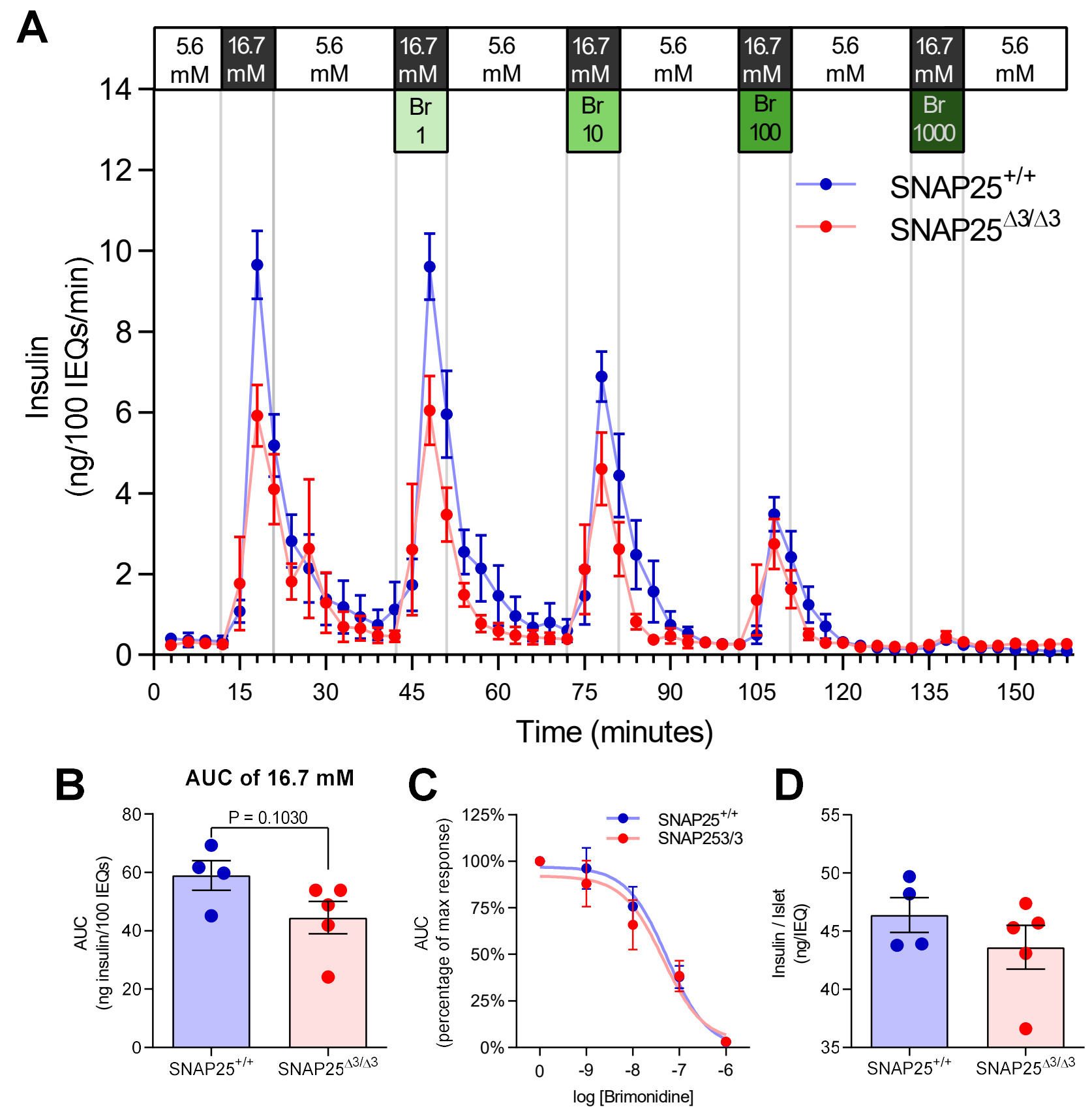

Figure 2. Ablation of the G $\beta$ Y-SNAP25 interaction does not alter glucose stimulated insulin secretion from islets ex vivo A. Perifusion of islets from 12 -week-old male SNAP $25^{+/+}$and SNAP $25^{\Delta 3 / \Delta 3}$ mice. B. Comparison of GSIS did not reveal a statistically significant difference between SNAP25 $5^{+/+}$and SNAP25 $23 / \Delta 3$ islets. C. AUC values were normalized to the individual's maximal GSIS and a dose-response curve for the inhibition of GSIS by the $\alpha_{2} A R$ selective agonist, brimonidine (Br), was generated. The log IC50's were similar, being -7.262 for SNAP25 $5^{+/+}$and -7.348 for SNAP25 $5^{\Delta / \Delta 3}$. D. Islet insulin content was not different between the two genotypes. $n$ $=4{\text { SNAP } 25^{+/+}, \mathrm{n}=5 \text { SNAP25 }}^{\Delta 3 / \Delta 3}$. Values are expressed as mean \pm SEM. 

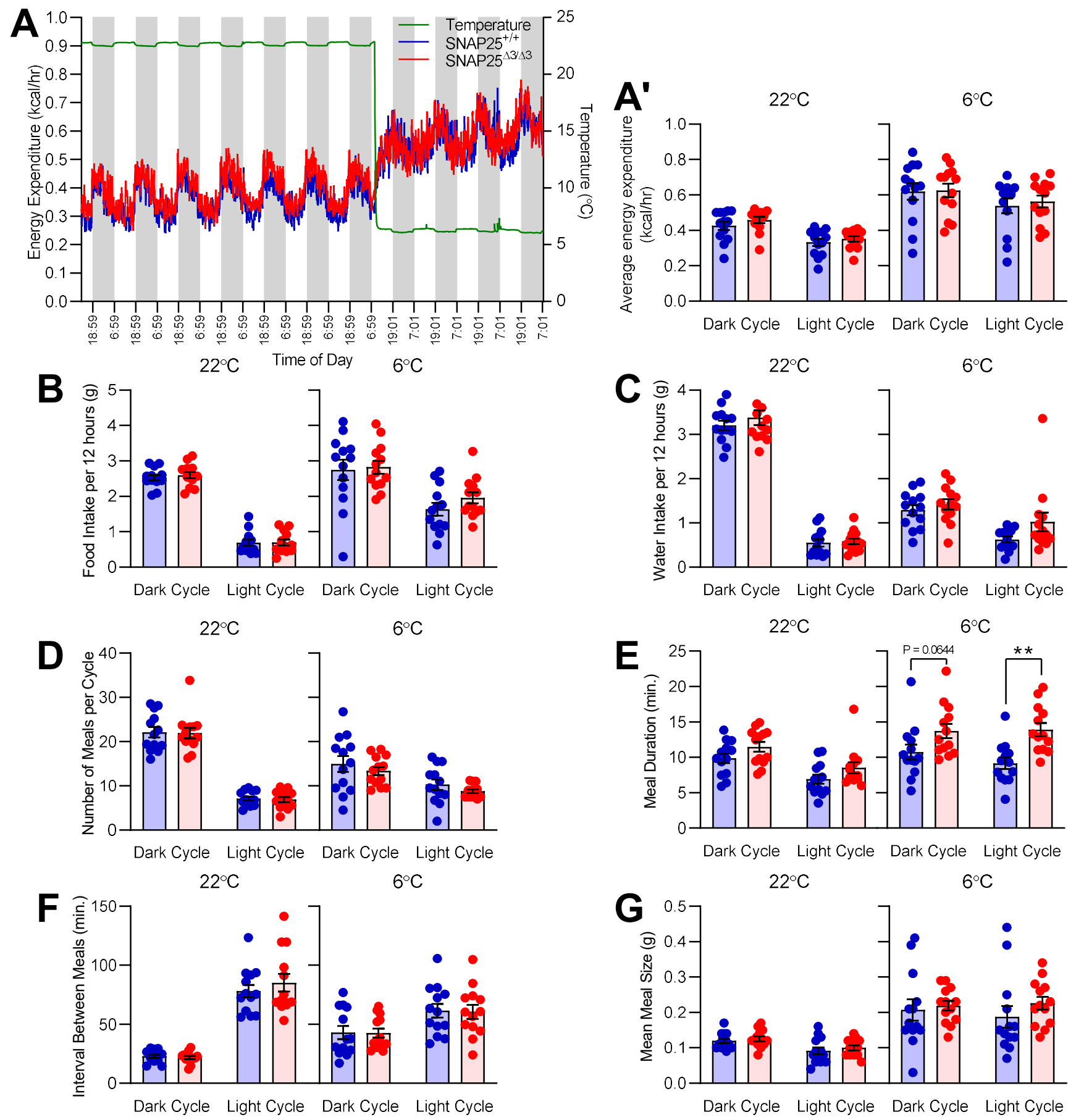

Figure 3. SNAP25 ${ }^{\Delta 3 / \Delta 3}$ mice have differences in feeding behavior but no difference in energy expenditure A. Energy expenditure was measured by metabolic cages at $22^{\circ} \mathrm{C}$ or $6^{\circ} \mathrm{C}$ (as indicated by green line) in young, lean, male SNAP2 $5^{\Delta 3 / \triangle 3}$ mice or SNAP $25^{+/+}$littermates ( $n=8$ each, $A^{\prime} n=13$ each). B. Food consumption and $\mathbf{C}$. water consumption were not different between genotypes. D. Differences in the number of meals was not statistically significant. E. However, meals consumed by SNAP2 $5^{\triangle 3 / \Delta 3}$ mice lasted for a longer period which was especially noticeable when housed at $6^{\circ} \mathrm{C}\left(\mathrm{P}=0.0050\right.$ for the effect of genotype at $\left.6^{\circ} \mathrm{C}\right)$. F. There was no noticeable difference for the interval between the meals. G. The size of the meal was also not changed. For $B-G, n=13$ for each genotype. ${ }^{*} p<0.05,{ }^{* *} p<0.01$, Bonferroni post-hoc comparison. Values are expressed as mean \pm SEM. 
bioRxiv preprint doi: https://doi.org/10.1101/2020.04.29.069138; this version posted April 30, 2020. The copyright holder for this preprint (which was not certified by peer review) is the author/funder, who has granted bioRxiv a license to display the preprint in perpetuity. It is made available under aCC-BY-NC-ND 4.0 International license.

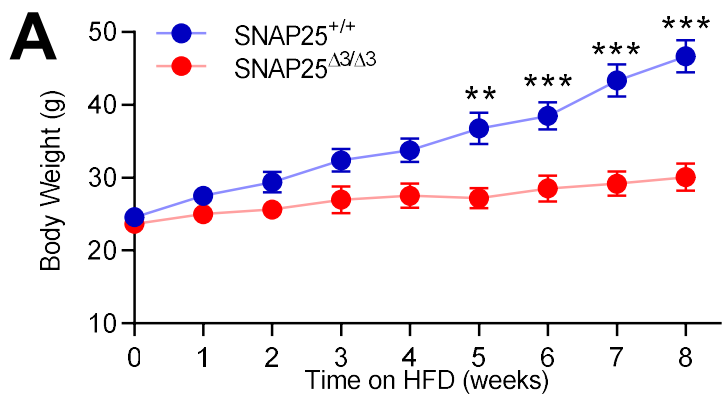

$\mathbf{A}^{\prime}$

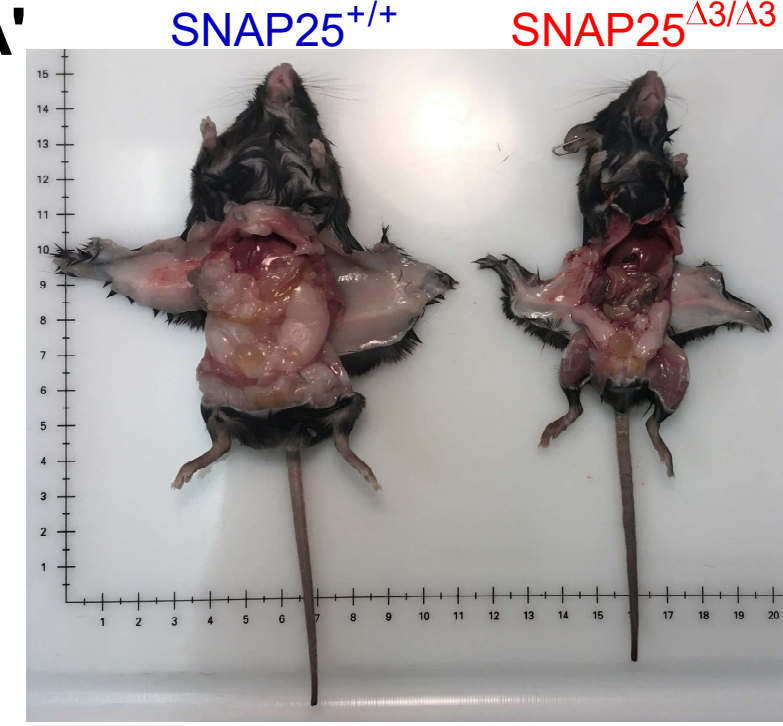

E
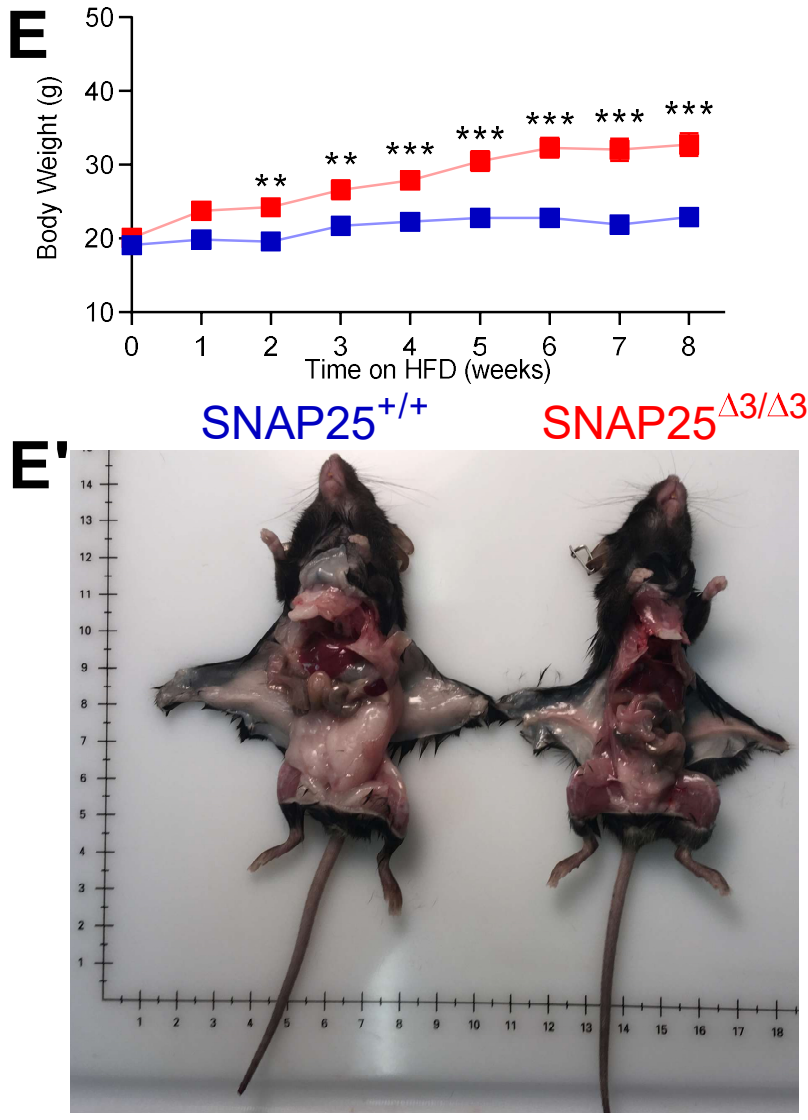
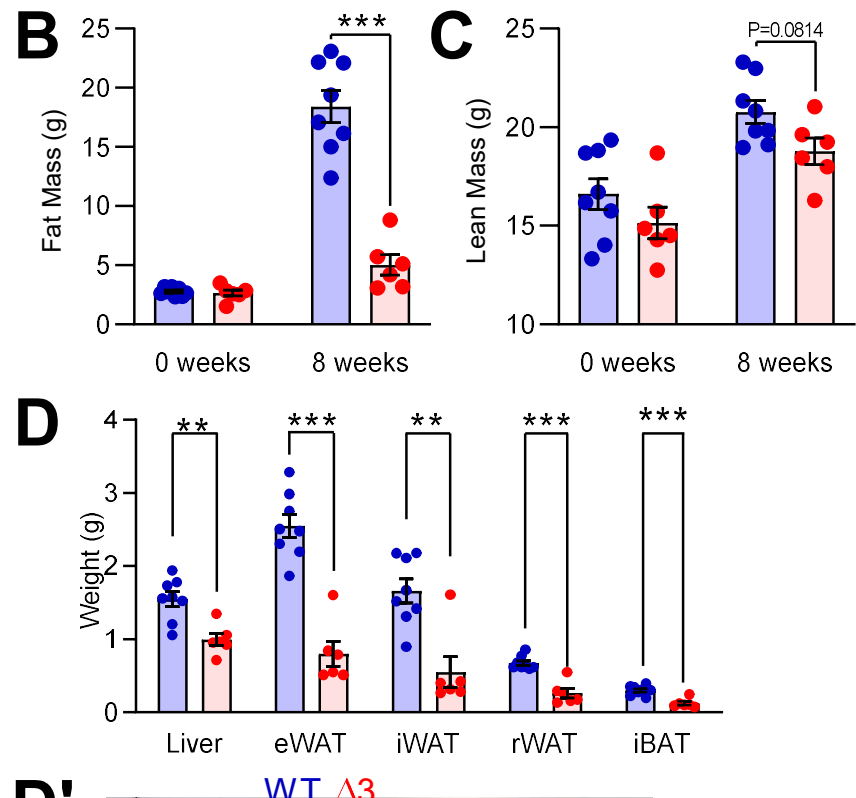

D'
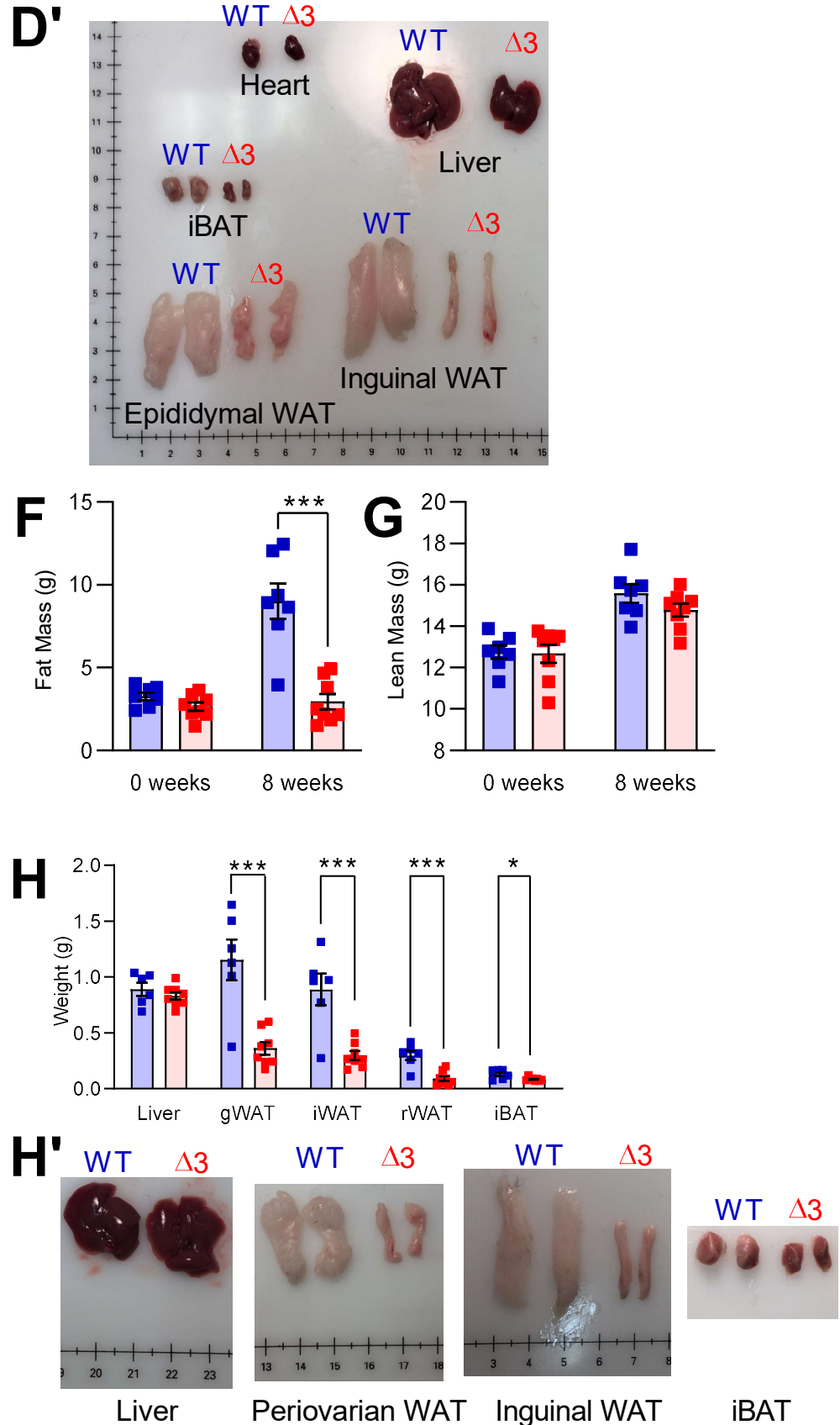

Periovarian WAT Inguinal WAT 
bioRxiv preprint doi: https://doi.org/10.1101/2020.04.29.069138; this version posted April 30, 2020. The copyright holder for this preprint (which was not certified by peer review) is the author/funder, who has granted bioRxiv a license to display the preprint in perpetuity. It is made available under aCC-BY-NC-ND 4.0 International license.

Figure 4. SNAP25 $5^{\Delta 3 / \Delta 3}$ male and female mice are resistant to diet-induced obesity

Male SNAP25 $5^{+/+}$and SNAP25 $5^{\Delta 3 / \Delta 3}$ mice were fed HFD beginning at 8 weeks of age. A. Male SNAP25 $5^{+/+}$mice became significantly heavier than SNAP25 ${ }^{\Delta 3 / \Delta 3}$ animals during the period of HFD feeding. Body composition was assessed at 4-week intervals by pulsed NMR. B. After 8 weeks of HFD feeding male SNAP $25^{+/+}$gained significantly more fat mass than SNAP25 $5^{\Delta 3 / \Delta 3}$. C. The male SNAP25 $5^{\Delta 3 / \Delta 3}$ mice tended to have less lean mass throughout the study $(P=0.0891$ for the effect of genotype). D. Liver and fat pads were weighed postmortem at the conclusion of the study. All adipose and liver tissues weighed were heavier in male SNAP25 $5^{++}$than in SNAP25 $5^{\Delta / \Delta 3}$ mice. E. Female SNAP $25^{+/+}$mice became significantly heavier than SNAP2 $5^{\Delta 3 / \Delta 3}$ animals during the period of HFD feeding. Body composition was assessed at 4-week intervals by pulsed NMR. F. After 8 weeks of HFD feeding female SNAP25 $5^{+/+}$gained significantly more fat mass than SNAP25 $5^{\Delta 3 / \Delta 3}$. G. Female SNAP25 $5^{\Delta 3 / \Delta 3}$ mice had similar less lean mass throughout the study. $\mathbf{H}$. Liver and fat pads were weighed postmortem at the conclusion of the study. All adipose tissues weighed were heavier in female SNAP25 $5^{+/+}$than in SNAP $25^{\Delta 3 / \Delta 3}$ mice, but liver weight were similar. For all figures, $n=8$ male SNAP $25^{+/+}, n=6$ male SNAP $25^{\Delta 3 / \Delta 3}, n=6-8$ female SNAP25 $5^{+/+}$, $\mathrm{n}=8$ female SNAP25 $23 / \Delta 3$. Values are expressed as mean \pm SEM. 

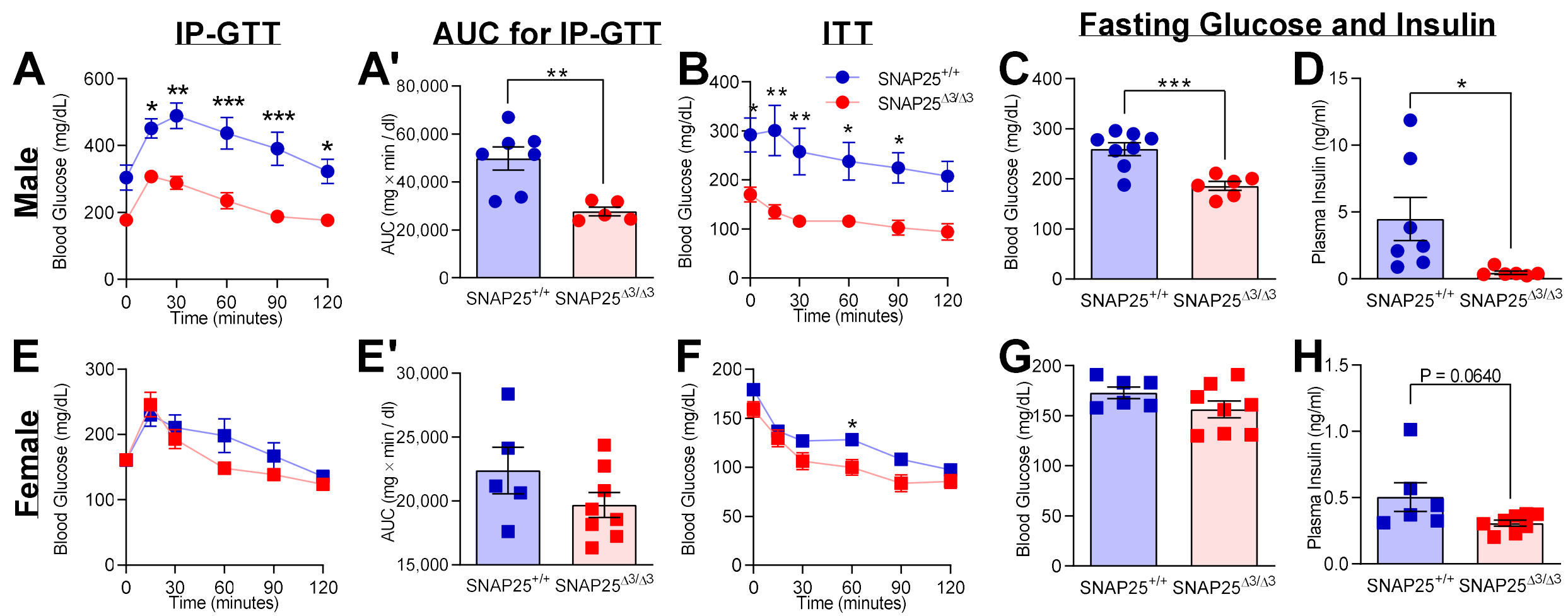

Figure 5. Male SNAP25 ${ }^{\Delta 3 / \Delta 3}$ mice have improved glucose and insulin tolerance when fed a HFD

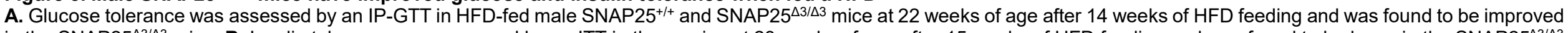

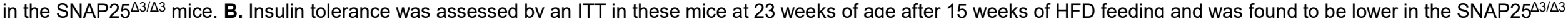

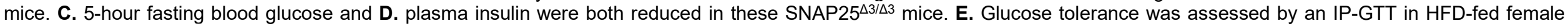

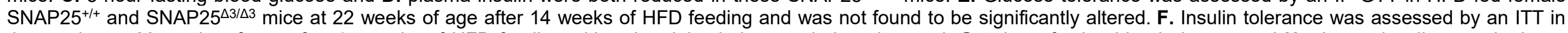

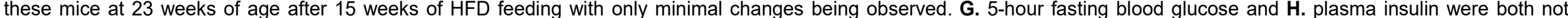

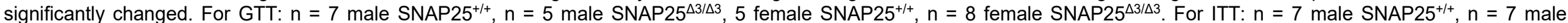
SNAP2 $5^{\Delta 3 / \Delta 3}, 5$ female SNAP $25^{+/+}, \mathrm{n}=8$ female SNAP25 $5^{\Delta 3 / \Delta 3}$. Values are expressed as mean \pm SEM. 
bioRxiv preprint doi: https://doi.org/10.1101/2020.04.29.069138; this version posted April 30, 2020. The copyright holder for this preprint (which

was not certified by peer review) is the author/funder, who has granted bioRxiv a license to display the preprint in perpetuity. It is made available under aCC-BY-NC-ND 4.0 International license.

A
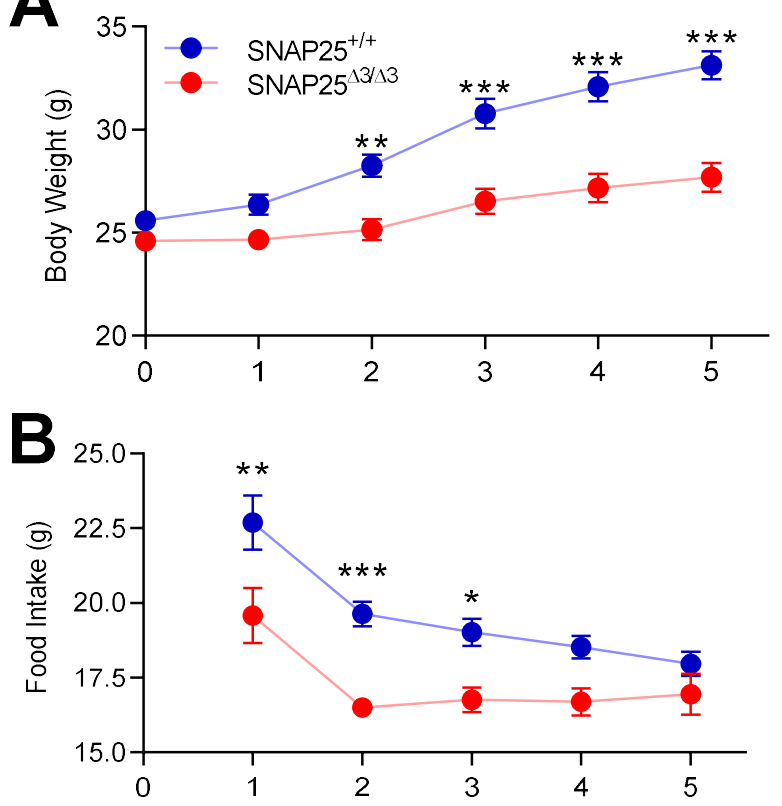

Figure 6. Male SNAP25 $5^{\Delta / \Delta 3}$ mice do not consume as much food as SNAP25 ${ }^{+/+}$when presented with a HFD

Male SNAP25 $5^{+/+}$and SNAP25 $5^{\Delta 3 / \Delta 3}$ mice were fed HFD beginning at 8 weeks of age and food consumption was measured weekly. A. SNAP $25^{+/+}$mice became significantly heavier than SNAP25 $5^{\Delta 3 / \Delta 3}$ animals during the period of HFD feeding. B. Food intake was initially lower in SNAP2 $5^{\Delta 3 / \Delta 3}$ mice but became similar after four weeks. $n=23$ SNAP2 $5^{+/+}, n=19$ SNAP25 $5^{\Delta 3 / \Delta 3}$. Values are expressed as mean \pm SEM. 
bioRxiv preprint doi: https://doi.org/10.1101/2020.04.29.069138; this version posted April 30, 2020. The copyright holder for this preprint (which was not certified by peer review) is the author/funder, who has granted bioRxiv a license to display the preprint in perpetuity. It is made available under aCC-BY-NC-ND 4.0 International license.
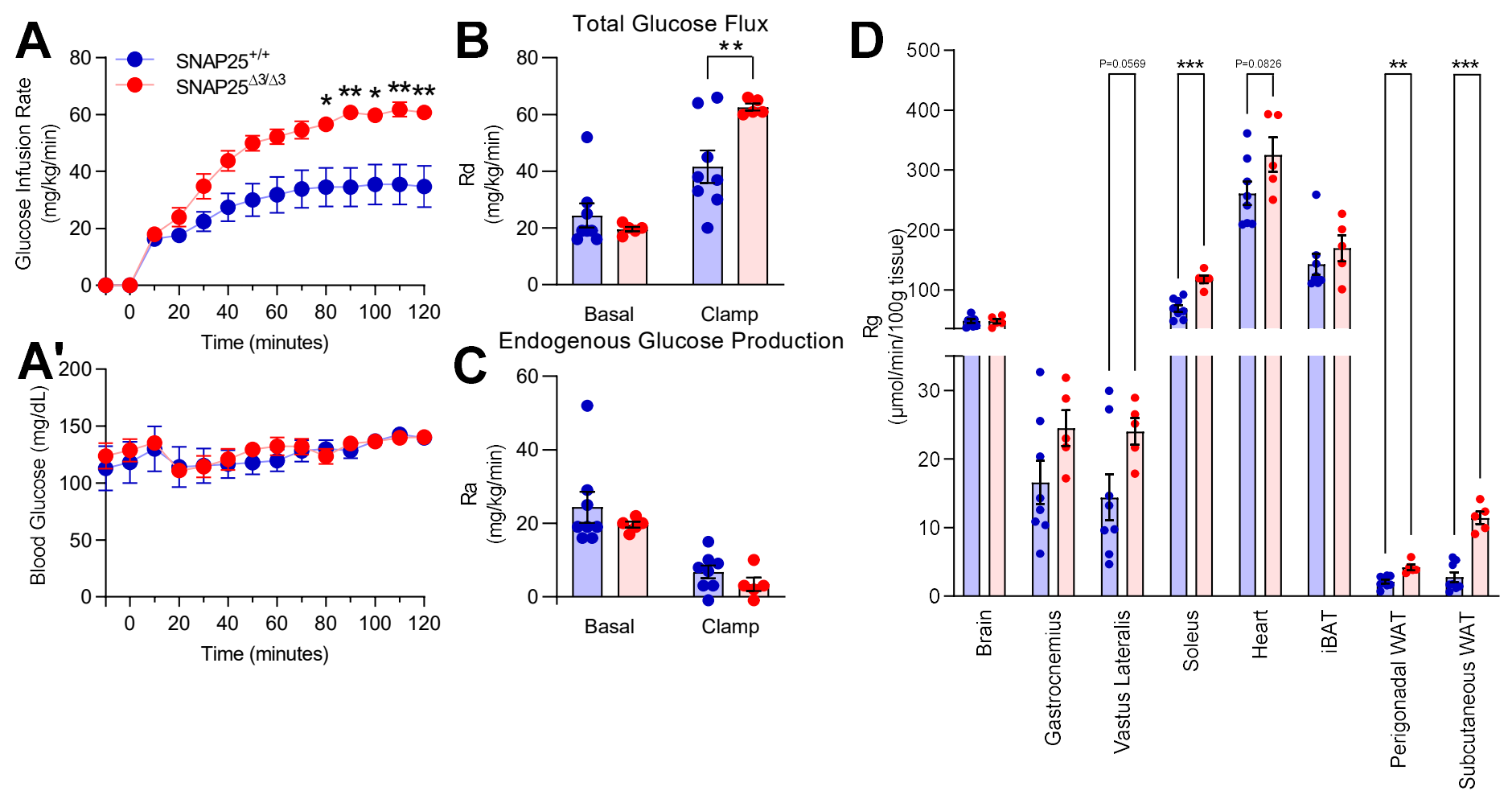

Figure 7. SNAP25 ${ }^{\Delta 3 / \Delta 3}$ mice have improved insulin sensitivity and increased glucose uptake in muscle and adipose tissues A. Glucose infusion rate was improved in male SNAP $25^{\Delta 3 / \Delta 3}$ mice during a hyperinsulinemic euglycemic clamp study $(P=0.0224$ for the effect of genotype). A'. During the clamp, the blood glucose was maintained at similar levels. B. The rate of glucose disposal was also increased in the SNAP25 $5^{\Delta 3 / \Delta 3}$ mice as compared to SNAP25 $5^{+/+}(P=0.0010$ for the effect of interaction). C. The rate of endogenous glucose production was not altered in SNAP25 ${ }^{\Delta 3 / \Delta 3}$ mice. D. Uptake of radiolabeled 2-deoxyglucose into the tissues revealed that SNAP2 $5^{\Delta 3 / \Delta 3}$ mice have greater glucose uptake in soleus muscle and white adipose tissue depots. $n=7 \mathrm{SNAP} 25^{+/+}, \mathrm{n}=5 \mathrm{SNAP} 25^{\Delta 3 / \Delta 3}$. Values are expressed as mean \pm SEM. 
bioRxiv preprint doi: https://doi.org/10.1101/2020.04.29.069138; this version posted April 30, 2020. The copyright holder for this preprint (which was not certified by peer review) is the author/funder, who has granted bioRxiv a license to display the preprint in perpetuity. It is made available under aCC-BY-NC-ND 4.0 International license.

\section{Male}

Female

\section{A. Inguinal White Adipose Tissue}
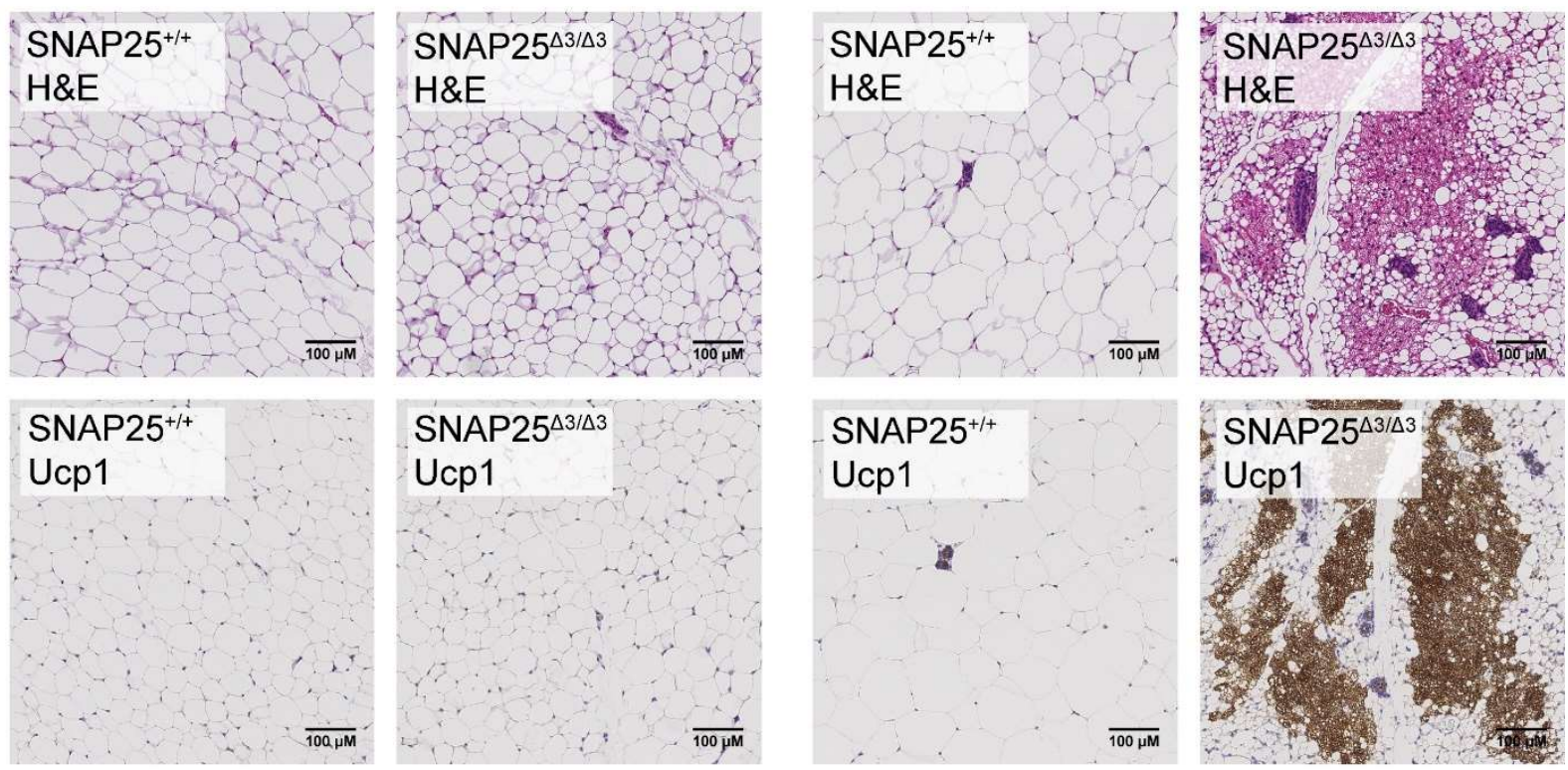

\section{B. Interscapular Brown Adipose Tissue}
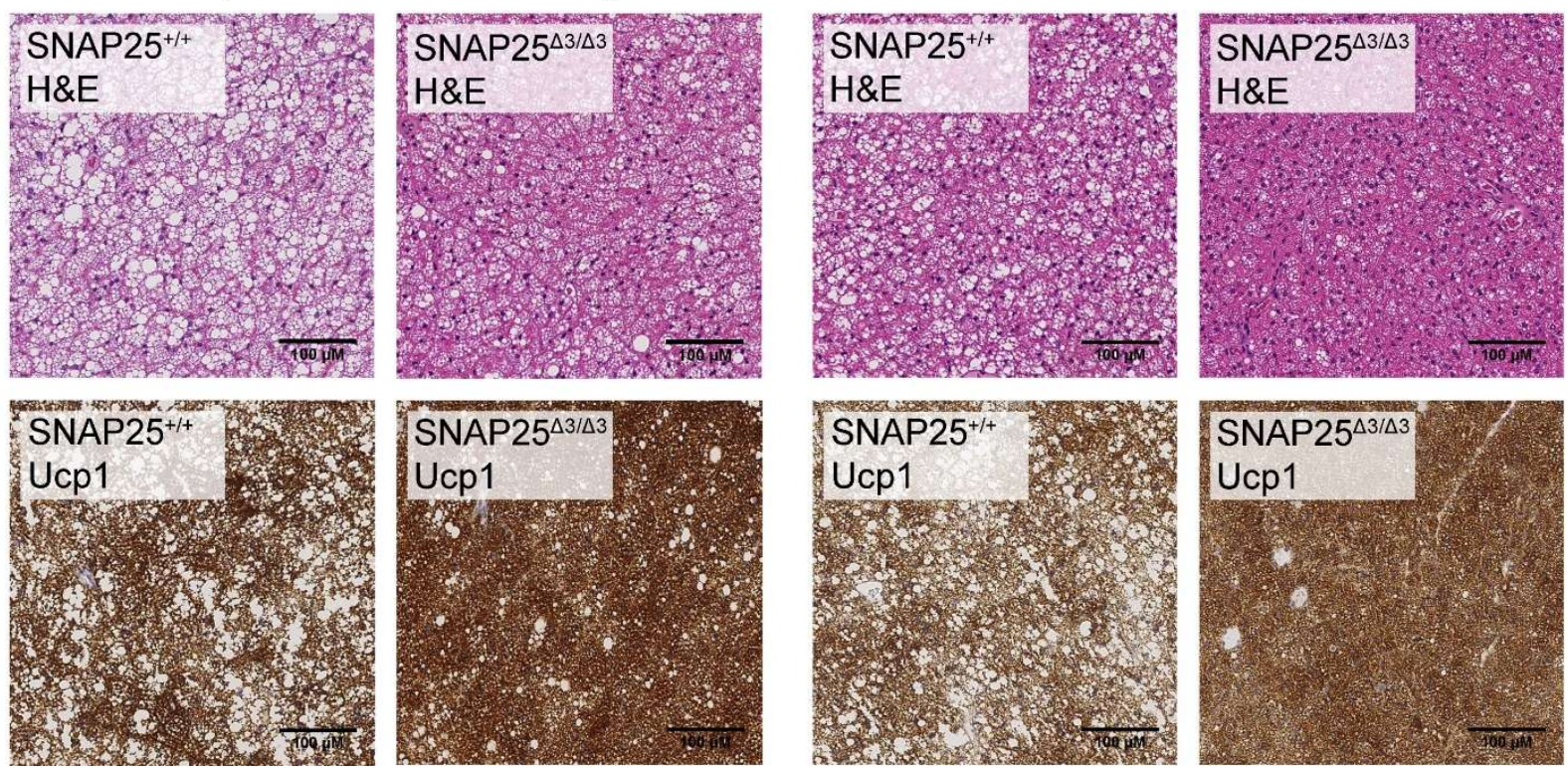

Figure 8. HFD fed SNAP25 $5^{\Delta 3 / \Delta 3}$ mice have improved adipocyte morphology and female SNAP25 $5^{\Delta 3 / \Delta 3}$ mice exhibit browning in inguinal white adipose depots

(A) Inguinal white adipose tissue (iWAT) and (B) interscapular brown adipose tissue (BAAT) were harvested from male and female SNAP $25^{+/+}$and SNAP25 $5^{\Delta 3 / \Delta 3}$ mice following 8 weeks on HFD. Representative H\&E- and UCP1-stained sections show that SNAP25 $5^{\Delta 3 / \Delta 3}$ mice had smaller adipocytes in both iWAT and iBAT. Furthermore, female SNAP25 $5^{\Delta 3 / \Delta 3}$ mice exhibited a marked increase in UCP1positively stained adipocytes in the iWAT. Images are a representative sample from 2 mice from each group. 


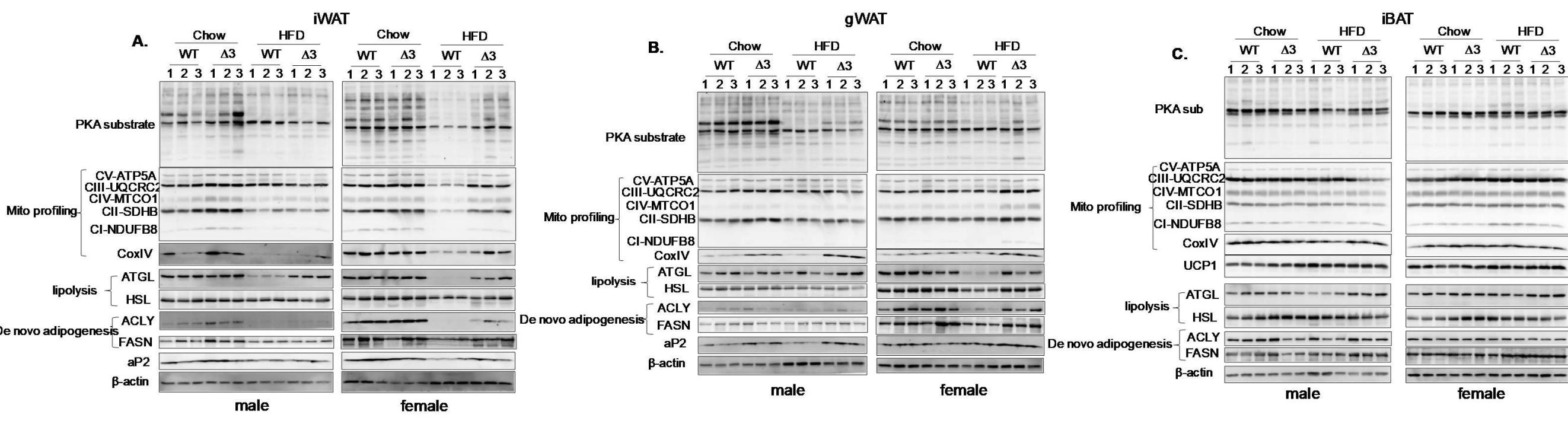

Figure 9. SNAP25 ${ }^{\triangle 3 / \triangle 3}$ mice have increased lipolysis, mitochondria markers, and PKA signaling in white adipose depots

(A) Inguinal white adipose tissue (iWAT), (B) gonadal white adipose tissue (gWAT), and (C) interscapular brown adipose tissue (iBAT) were harvested from male and female

SNAP25 $5^{+/+}$and SNAP25 $5^{\Delta 3 / \Delta 3}$ mice following 8 weeks HFD or chow feeding. Both iWAT and gWAT from SNAP25 $5^{\Delta / \Delta 3}$ mice exhibited increased markers of mitochondria and lipolytic activity. Western Blotting with and anti-RRXS $/ T^{*}$ (the PKA consensus sequence) antibody, indicated that PKA signaling was increased in SNAP25 $5^{\Delta 3 / \triangle 3}$ mice. 